\title{
Igualas, producción y mercado: las alcabalas novohispanas en la Receptoría de Cuautla de Amilpas (1776-1821)
}

\author{
Ernest Sánchez Santiró*
}

\section{Resumen}

Este artículo trata sobre las alcabalas novohispanas en la Receptoría de Cuautla de Amilpas, administración que presentó la peculiaridad de estar constituida por las igualas como principal rubro. Se analiza la problemática teórica y metodológica de esta fuente con el objetivo de explicar la dinámica económica de la región azucarera de Cuernavaca-Cuautla de Amilpas entre 1776 y 1821 .

\section{Abstract}

This paper deals with novobispanas sales taxes in Cuautla of Amilpas district. This administration had as its main element the igualas. In order to explain the economical dynamics of the sugar areas of Cuernavaca-Cuautla of Amilpas between 1776 and 1821, the paper analyses the theoretical and methodological problems involved in this source.
Palabras clave:

Fiscalidad, mercado novohispano, alcabalas, Cuautla de Amilpas.
Fecha de recepción: febrero de 2000 Fecha de aceptación: abril de 2000

*Profesor investigador de la Facultad de Humanidades de la Universidad Autónoma del Estado de Morelos. Correo electrónico: santiro@buzon.uaem.mx

Agradezco los comentarios de los doctores José A. Ibarra Romero y Jorge Silva Riquer, cualquier error u omisión es responsabilidad del autor. Este trabajo ha sido gracias al apoyo otorgado por el Conacyt. 
L os estudios de la evolución gene. ral de la economía novohispana durante el siglo XVIII, a partir de la fuente de alcabalas, han presenciado un amplio crecimiento a lo largo de los últimos años. Partiendo de los estudios pioneros $^{1}$ de R. S. Smith, A. Toledano o R. Pastor, y, fundamentalmente, de las aportaciones teóricas y metodológicas de J. C. Grosso y J. C. Garavaglia, se ha obtenido un conocimiento bastante amplio sobre las economías regionales, las estructuras de mercados, los mecanismos de circulación y distribución de mercancías o el abasto de mercados urbanos. En su análisis, las alcabalas de las administraciones foráneas de Puebla, Guanajuato, Michoacán y Guadalajara $^{2}$ han recibido una atención preferente, lo cual ha permitido la construcción de modelos de funcionamiento de los mercados novohispanos en el periodo que va de 1778 a 1810 , así como el diseño de una zonificación interna de dichas administraciones. La gran ausente en todo este panorama es una administración foránea ${ }^{3}$ vital, pero a la

\footnotetext{
'Smith, "Sales", 1948; Moreno, "Economía", 1972; Pastor, "Alcabala", 1977; Grosso y Garavaglia, Alcabalas, 1987; "Estado", 1987; "Marchands", 1989; Puebla, 1994; "Participación", 1994; Región, 1996.

${ }^{2}$ En el caso de Puebla ver las obras ya citadas de Grosso y Garavaglia, donde destaca la precisión de los estudios sobre Tepeaca. Para Michoacán, tenemos Silva Riquer, Administración, 1993; para Guanajuato Alvarado, Comercio, 1995; mientras que para Guadalajara ver Ibarra, "Mercado", 1995.

${ }^{3}$ Las administraciones foráneas fueron creadas en 1778 como parte del proceso de centralización de la renta de alcabalas. Fueron doce administraciones (Durango, Guadalajara,
}

vez problemática, México. Sus 21 receptorías abarcaban parte de lo que son en la actualidad los estados de Hidalgo, Querétaro, México, Morelos y Guerrero, y presentaban una gran diversidad productiva, étnica y de mercados. Dicha administración carece de un estudio global que ilustre sus peculiaridades y sus especiales relaciones con la ciudad de México y con sus receptorías subalternas.

Con este trabajo pretendemos analizar en detalle una receptoría de la administración foránea de México, Cuautla de Amilpas, con dos objetivos: observar las características del mercado intrarregional articulado alrededor de una producción altamente comercializable, el azúcar, y analizar los problemas metodológicos que implica investigar una receptoría donde las igualas superan las dos terceras partes de la recaudación total, y los consiguientes

Guanajuato, México, Oaxaca, Puebla, San Luis Potosí, Sonora, Valladolid, Veracruz, Yucatán, Zacatecas) que enviaban sus informes a la Administración General de Alcabalas, la cual se separó de la Superintendencia de la Aduana de la ciudad de México en 1778. En dicho año, cada administración foránea quedó integrada por diversas receptorias de alcabalas. En el caso de la administración foránea de México fueron 21 . Las receptorías eran centros locales de control administrativo de los intercambios comerciales. Todas ellas tenían un ministro del rey que hacía, entre otras, las funciones de recaudador. Finalmente, las receptorías estaban compuestas por los suelos alcabalatorios, las verdaderas "fronteras" mercantiles de Nueva España (cuyo traspaso implicaba el pago de la alcabala), que en algunos casos existían desde que se implantó dicha renta en 1575 . En 1778 existian doce administraciones foráneas, 96 receptorías de alcabalas y 161 suelos alcabalatorios. 
problemas a la hora de realizar un análisis de mercados. Finalmente, indicar que no hemos detenido el análisis en 1810 sino que lo hemos llevado hasta 1820 , con el objeto de mejorar el conocimiento sobre las grandes transformaciones que comportó el periodo bélico a la fiscalidad novohispana.

\section{ESTRUCTURA DE LAS ALCABALAS}

EN la RECEPTORÍA DE CuAuTLA DE AMILPAS

Situada en lo que es hoy el oriente del estado de Morelos, la Receptoría de Cuautla de Amilpas quedó constituida el 3 de octubre de 1776, tras el cese de los arrendamientos de las alcabalas en Nueva España. Su composición, integrada por los suelos alcabalatorios de Cuautla de Amilpas y Jonacatepec, fue la que se ve en el cuadro $1 .{ }^{4}$

La extensión de esta receptoría obedece a un matiz importante: se constituyó como un espacio fiscal que englobó a un territorio realengo, la alcaldía

\footnotetext{
${ }^{4} \mathrm{La}$ totalidad de las poblaciones era la siguiente: En la receptoría de Cuautla de Amilpas, tres cabeceras, Cuautla, Real de Huautla y $\mathrm{Za}$ cualpan más los siguientes pueblos de indios: Ocuituco, Jumiltepec, Ocahuasco, Ocajaltepec, Tlamimilulpan, San Miguel, Metepec, Tetela del Volcán, Hueyapan, Tlacotepec, Popotlan, Huasulco, Temoac y Tetelcingo. En el agregado de Jonacatepec, todos eran pueblos de indios, a saber: Yecapixtla, Tetelilla, Tlalistoc, Atlacahuayola, Xochiapa, Tepalcingo, Atotonilco, Amacuitlapilco, Amayucan, Jantetelco, Chalcalcingo, Jalostoc, Tlayacaque, Guichililla, Tecaxeque, Huechitlan, Gahuatlán y Achichipica. Archivo General de la Nación (en adelante AGN), vol. 617, foja 452.
}

mayor de Cuautla de Amilpas con sus agregados de Tetela y Ocuituco, y un territorio perteneciente a la jurisdicción del marquesado del Valle, la villa de Jonacatepec y Yecapixtla. ${ }^{5}$

Como receptoría de previsibles escasos ingresos, se estableció en ella un recaudador que cobraba un porcentaje de lo recaudado (10\% entre 1777 y 18 de enero de $1779,12 \%$ entre 1779 y 1820) y no un salario, tal y como sucedía en las principales aduanas. ${ }^{6}$ Este recaudador se encargaba también de la administración de tabacos, con lo cual una misma persona gestionaba lo que en la época se denominaron rentas unidas: alcabalas, pulques, pulperías, naipes, pólvora y tabacos, a las cuales, en 1796, se añadiría el indulto y la alcabala del aguardiente de caña. La hacienda virreinal apenas aumentaba sus costos y sus administradores mejoraban sus ingresos.

La Receptoría de Cuautla de Amilpas apenas representó $5.27 \%$ del total de la recaudación entre 1778 y 1809 , en el conjunto de la administración foránea, siendo la sexta en importancia, detrás de Querétaro, Toluca, Cuernavaca, Pachuca y Taxco, aunque fue creciendo

\footnotetext{
${ }^{5}$ Para ver el proceso de centralización de esta receptoría véase Sánchez Santiró, "Fiscalidad", 1999 (en prensa).

${ }^{6}$ AGN, Alcabalas, vol. 547 , exp. 39. Fueron doce los suelos alcabalatorios agregados a los administradores de tabacos, a saber: Apan, Coahuila, Cosamaloapan, Cuautla de Amilpas, Jalacingo, Jonacatepec, Otumba, Salamanca, San Juan de Llanos, Tuezitlán, Xicayan y Zempoala. "Informe de la División General de Aduanas de Nueva España", Archivo General de Indias (en adelante AGI), México, leg. 2091 (4 de febrero de 1779).
} 


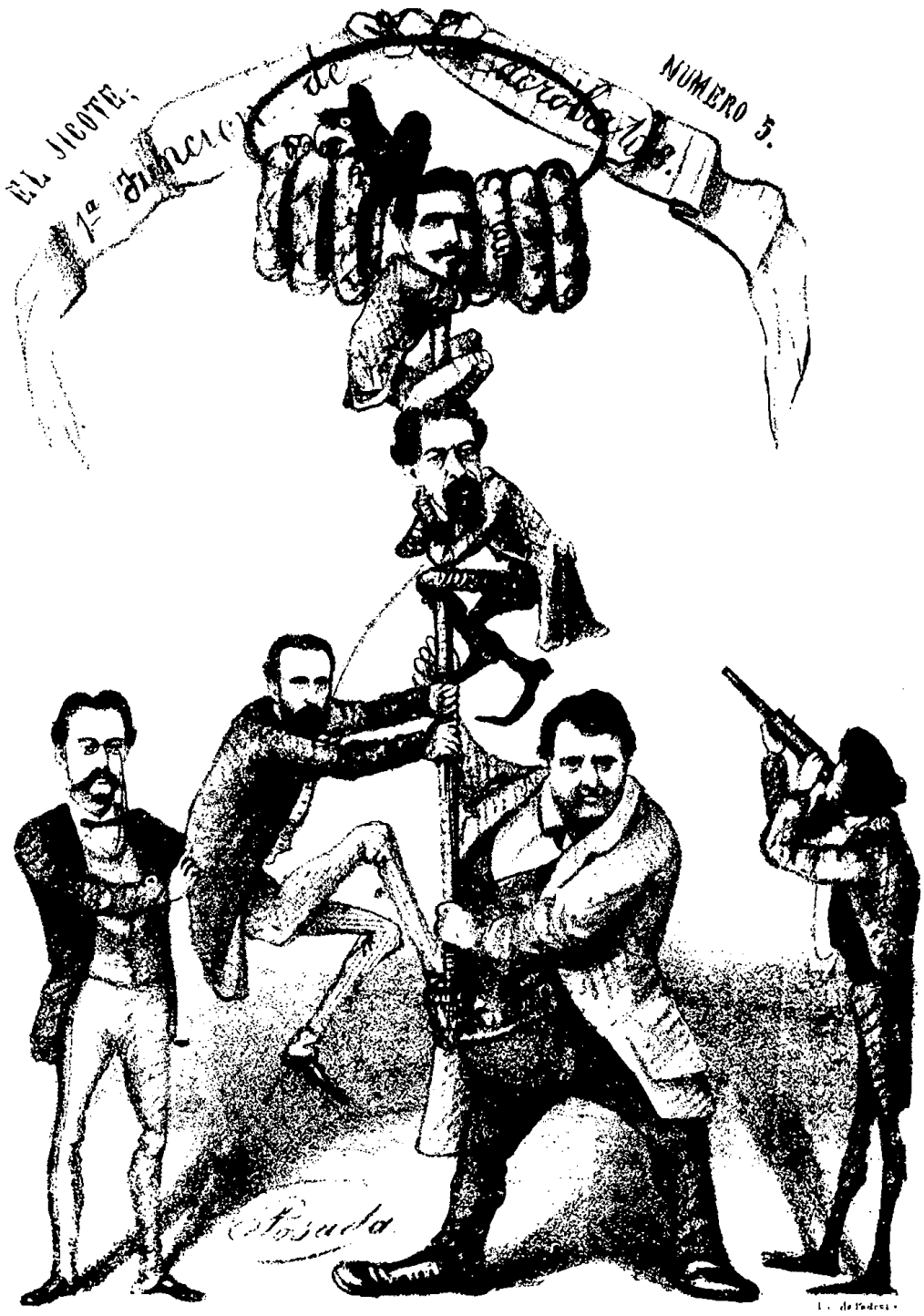


su importancia relativa a lo largo de ese periodo (ver cuadro 2 ). ${ }^{7}$

Entre 1777 y 1820 , la receptoría de alcabalas de Cuautla de Amilpas abarcaba cuatro grandes espacios económicodemográficos. Primeramente, la zona de tierra caliente, donde se desarrollaron las haciendas azucareras de la alcaldía mayor de Cuautla de Amilpas y la villa de Jonacatepec. En segundo lugar, el Real de Minas de Huautla, un núcleo minero en decadencia, que consiguió subsistir a lo largo de los siglos XVII y XIX dada su proximidad al gran mercado de la ciudad de México. En tercer lugar, una zona de ranchos situada entre las haciendas de Cuautla y el núcleo minero del sur. Finalmente, un territorio de economía campesina en la zona montañosa al pie del Popocatépetl (Tetela del Volcán, Ocuituco, Zacualpan y Yecapixtla) y la llanura de las Tlalnaguas, al sur de Jonacatepec. ${ }^{8}$

A esta estructura productiva correspondió una composición demográfica mayoritariamente indígena $(66 \%$ del total) distribuida desigualmente, de forma que la población de las haciendas, ranchos y minas fue, por orden de importancia, mulata, mestiza y española, mientras que en las zonas de economía campesina, la población indígena fue la mayoritaria (entre 75 y $90 \%$ ). Esta desigual distribución económicodemográfica fue la causa de la diferente composición y del monto de la recau-

\footnotetext{
${ }^{7}$ La comparación la realizamos a partir de las cifras de los septenios aportados por Grosso y Garavaglia, Región, 1996, p. 111.

${ }^{8}$ Mentz, Pueblos, 1988, Trabajo, 1999 y Sánchez, "Población", 1998.
}

dación entre los dos suelos alcabalatorios que formaban la receptoría (ver cuadro 3 ).

A pesar de estar más poblado el suelo alcabalatorio de Jonacatepec, fue en el de Cuautla donde se recaudó la mayoría de la renta de alcabalas (68.1\%), en correspondencia con la presencia de una mayoría de haciendas, ranchos y minas, y donde se asentó una población compuesta étnicamente por mulatos, mestizos y españoles (casi $40 \%$ de la población de la alcaldía mayor de Cuautla en 1777). En este último caso, dado que la mayor parte de los comerciantes de la Receptoría eran españoles y castizos, sus ventas sí pagaban alcabala, ${ }^{9}$ mientras que en virtud de la legislación virreinal, la población india estaba excluida del pago de la misma.

La distribución porcentual de los distintos rubros que componían las alcabalas de Cuautla de Amilpas, fue la que se muestra en el cuadro $4 .^{10}$

${ }^{9}$ AGN, Padrones, vol. 8.

${ }^{10} \mathrm{De}$ los 42 años que abarcan el periodo de estudio, hemos podido desglosar la composición de $50 \%$ de ellos. AGN, Aduanas foráneas, Real Hacienda-Indiferente y Alcabalas, vol. 317. El viento representaba "fundamentalmente las transacciones de los más pequeños y medianos productores y de los mercaderes de muy poca entidad ligadas al ámbito de la actividad económica local [...] el rubro de igualas se compone principalmente de las partidas pagadas por hacendados, rancheros y pegujaleros por los efectos de la propia producción que podían llegar a vender o trocar directamente en las propias unidades agrarias", Grosso y Garavaglia, Región, 1996, p. 70 (la cursiva es mía). Como ya vere. mos, en Cuautla de Amilpas, en el caso de las igualas, hay que agregar a los principales comerciantes de Cuautla, Jonacatepec, Yecapixtla, Zacualpan y el real de Huautla, lo cual hace un 
Esa composición nos muestra una receptoría donde los dos rubros que marcan las transacciones intrarregionales (igualas y viento), dominan de forma abrumadora: $83 \%$ del total, incluyendo ventas de inmuebles, y $92 \%$ sin éstas. Por el contrario, las ventas procedentes del mercado virreinal y europeo apenas alcanzan $8 \%$ del total recaudado. En el caso de las ventas procedentes del virreinato, el ganado (reses, toros, carneros y mulas) llegó a representar $65 \%$ del total de ventas de efectos de la tierra; ventas realizadas mayoritariamente en las haciendas azucareras de Cuautla de Amilpas, Jonacatepec y Jantetelco, con el propósito de cubrir parte de las necesidades de alimentación de su población residente, así como las labores agrícolas y el transporte de productos. Otra parte de estas ventas de ganado se realizaban en las cabeceras de Cuautla y Jonacatepec para abastecer de carne a estas poblaciones.

En cuanto a que el rubro de las igualas fue el mayoritario en esa receptoría, la recaudación presenta una gran estabilidad a lo largo del año, lo cual no obsta para que se detecten ciertas variaciones de interés (ver gráfica 1).

En el conjunto de los años en que se ha podido separar la recaudación mensual de Cuautla y Jonacatepec (1778-1793) se aprecia, como ya dijimos, una gran estabilidad interrumpi-

poco más compleja la situación, de forma que no podemos hacer la siguiente equivalencia: iguala $=$ ventas de parte de la producción local . Para una explicación más amplia del contenido de cada uno de los rubros de alcabalas véase Garavaglia y Grosso, Alcabalas, 1987. da únicamente por tres motivos. Primeramente, en el suelo alcabalatorio de Jonacatepec se realizaba la feria de Tepalcingo durante los meses de febrero o marzo (dependiendo de cuándo fuese el tercer viernes de Cuaresma), que era una de las principales ferias del centro de Nueva España en la modalidad de tianquiztli. ${ }^{11}$ En ella, cientos de indígenas de la sierra de Puebla, plateros y comerciantes de Puebla, México y Cuernavaca acudían a realizar sus ventas (en especial, ahí eran famosas las jícaras procedentes de Olinalá). Su importancia era tal que la recaudación del viento de la Feria de Tepalcingo equivalía, en promedio, a $13 \%$ anual de toda la recaudación de Jonacatepec. ${ }^{12}$

En segundo lugar, cuando se negociaba alguna propiedad inmueble de gran valor (fue el caso de la venta de la hacienda de Tenextepango en 1787), su inclusión en los libros de alcabalas hacía que ascendiese claramente la recaudación, aunque esto no fuese sinónimo de pujanza económica.

Finalmente, constatamos cómo la recaudación volvía a aumentar en los meses de noviembre y diciembre. Esto obedecía a tres motivos básicos: al finalizar el año se hacía efectivo el pago de la alcabala de las ventas realizadas por los rancheros pegujaleros del Real de Huautla, Yecapixtla y Jonacatepec, por concepto de impuesto a la carne, la leche y el queso vendidos durante

${ }^{11}$ Toledano, Tepalcingo, 1996, pp. 180-192.

12 Los años en los que hemos podido desglosar el viento de Tepalcingo del de toda la receptoría representan $35.7 \%$ del total de años considerados, a saber: $1778,1779,1789,1794$, $1800,1802-1803,1805-1810,1815$ y $1817-1818$ 
ese año; asimismo se producían importantes ventas de ganado -en especial reses para consumo de carne- en las cabeceras de Cuautla y Jonacatepec entre la población de dichos núcleos, además de que durante el mes de diciembre se hacía efectivo el pago de la alcabala correspondiente a las ventas de los "repartidores" de mercancías importadas entre las poblaciones indígenas de la receptoría, especialmente en el suelo de Jonacatepec. Esto último era la manifestación fiscal de la actividad mercantil impuesta a dichas poblaciones por medio del repartimiento.

Respecto al comercio indígena y a sus relaciones con los comerciantes españoles de la zona es bastante poco lo que sabemos. Únicamente de 1792 podemos obtener una aproximación de su participación en el mercado, debido a la consulta ordenada por el segundo conde de Revillagigedo; consulta que tuvo el objeto de conocer el volumen de la alcabala no recaudada por la corona, por la exención de que disfrutaba la población indígena. ${ }^{13}$

Los productos vendidos en 1792 por los comerciantes indígenas en el suelo de la receptoría, alcanzaron un valor total de 3609 pesos. Por la ausencia destacable del maíz, se puede concluir que la participación indígena en el mercado intrarregional era escasa. Las ventas mensuales apenas alcanzaban los

${ }^{13}$ Garavaglia y Grosso, Alcabalas, 1987, pp. 18-22. "Cuaderno en que, por método de estado, se apuntan los géneros, frutos o efectos que introducen o venden diariamente los indios con expresión de sus nombres, valores y la alcabala que deja de cobrarse desde 1 de enero hasta fin de diciembre de 1792", AGN, Aduanas foráneas, Real Hacienda-Indiferente.
300 pesos, frente a los 19000 pesos de ventas mensuales efectuadas -en promedio- en la receptoría.

Estos productos se agrupaban en dos grandes bloques: productos artesanales (66\%) y alimentos (44\%) (véase cuadro 5).

Según este panorama, podría parecer que la población indígena estaba escasamente monetarizada, máxime cuando 21 localidades de la jurisdicción, todas ellas pueblos de indios, carecían de comercio estable. ${ }^{14}$ Sin embargo, hay que tener en cuenta dos factores en relación con el proceso de monetarización e integración de la población indígena de esta receptoría a los circuitos mercantiles. Por una parte, sabemos que importantes contingentes de su población se trasladaban varios meses del año a las haciendas azucareras para laborar sus campos, recibiendo un jornal en metálico, ya fuese directamente o través de los "recogedores de indios". ${ }^{15}$ Dinero que ayudaba a las comunidades a cubrir, entre otras cosas, el tributo, las obligaciones del diezmo, los pagos a las cofradías, así como los adelantos obtenidos en los repartimientos de mercancías. La hacienda azucarera mercantilizaba así a parte de la población indígena.

Además, comparando las ventas de ese núcleo de comerciantes indígenas con las realizadas por los pequeños co-

\footnotetext{
14 "Libro de Igualas de 1777 de Cuautla de Amilpas", AGN, Aduanas foráneas, Real Hacienda-Indiferente.

${ }^{15}$ Mentz, Trabajo, 1999, pp. 281-291. Hay que indicar que esto último era algo poco fre. cuente a finales del siglo xvi (en el ámbito de las haciendas azucareras de la región de Cuernavaca y Cuautla de Amilpas).
} 
merciantes españoles, castizos y mestizos propietarios de sangarros o tendajos, ${ }^{16}$ podemos constatar cómo su participación en el mercado tiene cierta relevancia. Así, en los libros de igualas de 1789 , aparecen trece pequeños comerciantes que aportaban 345 pesos al total de dicho rubro (8\%), lo cual implicaba unas ventas anuales de 4312 pesos, frente a los 3609 pesos realizados por mercaderes indígenas. Por tanto, ambos grupos ocupaban un espacio muy similar en el mercado de la receptoría (1.8\% y $2.1 \%$ respectivamente) y competían por un mismo tráfico: el pequeño consumidor.

\section{LAS IGUALAS COMO PACTO ECONÓMICO}

Por lo que llevamos dicho vemos que una de las claves de las alcabalas de Cuautla de Amilpas fueron las igualas celebradas con hacendados, comerciantes y rancheros. No poseemos un estudio global del virreinato sobre este punto, pero los estudios de Juan Carlos Grosso y Juan Carlos Garavaglia parecen indicar que tales igualas llegaron a representar el $11 \%$ de la recaudación total de alcabalas, ${ }^{17}$ aunque en determinadas receptorías representaron más del $70 \%$, caso de Cuernavaca, Zacatlán (en Puebla) o Cuautla de Amilpas.

${ }^{16}$ Tales son las denominaciones de las pequeñas tiendas en la receptoría. La comparación la realizamos con el libro de igualas conservado más próximo a 1792, en concreto es el libro de 1789. AGN, Aduanas foráneas, Real Hacienda-Indiferente.

${ }^{17}$ Grosso y Garavaglia, Región, 1996, p. 68.
En el último tercio del siglo xviı, una iguala era una "composición, ajuste o pacto en los tratos, compras o ventas", 18 en la cual no se incluían las ventas realizadas en otros suelos alcabalatorios. Sabemos por la legislación virreinal, que la alcabala se abonaba donde se introducía o vendía la mercancía, y no donde se expedía, lo cual hace que la práctica totalidad de las ventas de azúcar, aguardiente y miel de las haciendas y fábricas de Cuautla de Amilpas no aparezcan registradas allí, sino en las aduanas dependientes de la ciudad de México y Puebla, sus principales mercados.

La existencia de las igualas dentro de la renta de alcabalas implicaba que la administración novohispana era incapaz de fiscalizar, en su totalidad, el movimiento mercantil. En palabras del administrador de la receptoría de Cuernavaca, José Antonio Aparicio, al director general de las administraciones foráneas, Juan Navarro Madrid: "Las igualas son aquellas que se celebran con las partes para asegurar lo que se pueda de lo que no se sabe ni se puede averiguar". 19

Esta incapacidad hay que entenderla por dos motivos. Primeramente, porque extender el control fiscal del tráfico mercantil hasta los más lejanos lugares o a las innumerables pequeñas transacciones hubiese sido factible, pero su costo hubiese implicado un drenaje cada vez mayor de la recaudación, mismo que no formaba parte de la políti-

\footnotetext{
${ }^{18}$ Diccionario de Autoridades, Real Academia Española de la Lengua, Madrid, 1775.

${ }^{19} \mathrm{AGN}$, Alcabalas, vol. 28, fs. 208-208v. (la cursiva es mia).
} 
ca fiscal de los Borbones. ${ }^{20}$ Las igualas solucionaban este inconveniente.

En segundo lugar, pero más importante, porque esta incapacidad manifestaba la tensión política generada en torno a la fiscalidad mercantil. En este sentido, nos interesa destacar en la definición del Diccionario de Autoridades, el concepto de iguala como "pacto". La iguala representaba el mantenimiento de parte del sistema de recaudación existente con anterioridad a la centralización ordenada por Carlos III en 1776: los arriendos con particulares o corporaciones y los encabezamientos -padrón para el impuesto- con el común del comercio y los vecinos de las localidades. De ahí que el superintendente de la Aduana de México, Miguel Páez de la Cadena, se refiera varias veces a las igualas como "arriendos parciales", en tanto que eran condicionales y por el plazo máximo de un año. Una prueba de esta parcial prolongación del sistema anterior a 1776 lo tenemos en la receptoría de Cuautla de Amilpas. En una carta del primer administrador de la renta de alcabalas de Cuautla de Amilpas, el licenciado Juan Antonio Canseco a Miguel Páez de la Cadena, observamos:

${ }^{20} \mathrm{AGN}$, Alcabalas, vol. 419 , exp. 47 , fs. 213 247. Además de administrar la renta de tabacos, pulques, pulperías y pólvora, el recaudador de la renta de alcabalas de Cuautia tenía que controlar más de 130 establecimientos, en concreto: 64 ranchos, 39 tiendas, once purgares y tiendas de haciendas, nueve tendajos, además de nueve repartidores de diversos efectos y ropa, amén de los tianguis en las seis principales localidades y la feria anual de Tepalcingo. AGN, Aduanas foráneas, Real Hacienda-Indiferente (1777).
[Antes de 1777] los diputados de estas jurisdicciones $[\ldots]$ tenían hechas sus igualas de modo que cada uno cobraba lo que le pertenecía de viento en todo el distrito de su hacienda o casa, incluyendo en dicha Iguala todos sus comercios, de esa manera que eran todos libres para entrar de una a otra jurisdicción sin que hubiera quien lo impidiese. En el día los tengo igualados, por lo que cada cual vende en su tienda o hacienda, de suerte que si fuera del umbral de la puerta vende algún tendero alguna cosa se le cobra alcabala [...]. Todo mi cuidado consiste en saber quién vende lo qué y a quien. ${ }^{21}$

El sistema de igualas manifestaba la capacidad de negociación y presión de determinados sectores de la producción y el comercio frente a la Hacienda Real, máxime cuando no se trataba de remotos parajes ni de escasísimos ingresos, que es lo que parecería desprenderse de la documentación virreinal. Ninguno de estos calificativos podían darse a las ventas de comerciantes y hacendados de dos receptorías tan significativas como Cuernavaca y Cuautla de Amilpas, es decir, los principales núcleos productores de azúcar, aguardiente, miel y piloncillo de Nueva España.

Este acuerdo no estaba exento de conflictos entre hacendados, rancheros, propietarios de obrajes y comerciantes frente a los ministros de la corona, tal y como lo podemos comprobar en una misiva de 1793 de Juan Navarro Madrid al administrador de la aduana de Pachuca:

${ }^{21}$ AGN, Aduanas foráneas, Real Hacienda-Indiferente (carta de 1 de febrero de 1778). 
[Los administradores] por más que empeñen su celo para interiorarse en los comercios de los individuos con quienes las efectúan, no es posible adquieran los conocimientos que éstos poseen de sus comercios, por lo que si el comerciante conviene en la iguala que le propone el administrador, es porque sin equivocación conoce que con ella satisface menos alcabala que la que adeuda, y se resiste al contrario siempre que llega o excede a su fruto. ${ }^{22}$

Estas tensiones se intensificaron con el cambio de centuria. No es extraño que en el preciso momento en que, como resultado de la política imperial de los Borbones, se dispararon los niveles de endeudamiento de la Real Hacienda, ${ }^{23}$ se intentase obtener más ingresos cambiando el régimen seguido con las igualas desde 1776.

Una vez más es el administıador de alcabalas de Cuernavaca, receptoría con un sistema de recaudación constituido sobre el mismo tipo de economía y con los mismos patrones de recaudación que la de Cuautla de Amilpas, el que nos aporta las claves del conflicto. En la correspondencia de 1805 y 1806 se detecta una tensión creciente, tanto en Cuautla como en Cuernavaca, por el incumplimiento de diversos hacendados con la obligación de sacar guías y pases para realizar su comercio. Tras diversos informes que no fueron del agrado del director general del ramo, Juan Navarro, éste envió una orden al administrador de Cuernavaca, José Antonio Aparicio, para que procediese a la reforma de las igualas, "cuando com-

${ }^{22}$ AGN, Alcabalas, vol. 547, fs. 15-16.

${ }^{23}$ Marichal, "Guerras", 1990, pp. 904-905. prueben que las igualas que hayan celebrado, perjudican a la Real Hacienda".

Hasta aquí no hay novedad, dado que era lo aceptado por la Real Hacienda de que la iguala siempre perjudicaba económicamente al erario real, aunque social y políticamente significase una trato diferencial que comportaba la adhesión de los comerciantes y los hacendados beneficiados. El problema aparecía en la contestación del administrador:

Me hallo perplejo para proceder [...] [ya que] las igualas del comercio activo y pasivo de esta jurisdicción de mi cargo, se establecieron desde el año de 1777 , en que dio principio esta cobranza por cuenta de la Real Hacienda y se ha seguido hasta el presente, sin otras reglas que aquellas que ha dictado la necesidad de acomodarse $m$ is antecesores y yo a las propuestas que ban becho $y$ bacen los inquilinos contribuyentes, a espaldas de las dificultades de averiguarles sus comercios. ${ }^{24}$

Es decir, no era la administración la que establecía la iguala, sino los productores y comerciantes. La presión de la Dirección General de Alcabalas implicaba proceder a la averiguación de la legitimidad de los conciertos establecidos, a lo cual el administrador de Cuernavaca respondía: " $\mathrm{He}$ de estrechar a los hacendados, comerciantes y cosecheros de aguardiente a la presentación de los libros y apuntes de sus comercios?"

Proceder a esto hubiese significado la ruptura del pacto inicial que asegu-

${ }^{24}$ AGN, Alcabalas, vol. 28 , fs. 182-183, y Real Hacienda-Indiferente, Aduanas foráneas (Cuernavaca y Cuautla, 1806) (la cursiva es mía). 
ró una recaudación creciente (como ya veremos) a la corona, pero insuficiente a la altura de 1806. Desconocemos la respuesta de las autoridades, pero observando la recaudación en concepto de igualas de Cuautla de Amilpas entre 1806 y 1811, constatamos que no hubo ningún cambio destacable ni en sus montos ni en su composición, por lo que hay que suponer que en este conflicto acabó triunfando el polo de los productores y comerciantes, algunos de los cuales, Gabriel del Yermo (en Cuernavaca) o Manuel y Martín Michaus (en Cuautla de Amilpas) eran importantes titulares de préstamos concedidos a la monarquía y miembros de instituciones tan influyentes como el Consulado de la ciudad de México. Esta situación se mantuvo durante el periodo de los disturbios bélicos posteriores a 1811 .

\section{LAS IGUALAS EN LA RENTA DE}

\section{ALCABALAS DE CUAUTLA DE AMILPAS (1777-1820)}

Vimos cómo Cuautla de Amilpas fue administrada mediante la iguala como método mayoritario de recaudación. En concreto, ésta representó $68 \%$ del total, contando las ventas de bienes raíces, y $74.1 \%$ sin éstas. El restante $25.9 \%$ se repartía, por orden de importancia, entre el viento, los bienes de la tierra y los de Castilla. Por tanto, de su evolución dependió el currso de la renta.

Uno de los problemas principales de estas igualas es conocer qué significaban realmente. En general, se interpreta que venían a ser una expresión de las partidas pagadas por los hacen- dados, rancheros y pegujaleros por los efectos de la propia producción vendidos o trocados en los núcleos agrarios. ${ }^{25}$ Por tanto, una receptoría en expansión, como era el caso de la de Cuautla de Amilpas, con crecientes necesidades de mano de obra, insumos y capital (el cual era conseguido, en su mayoría, por diversos mecanismos de crédito que generaron unidades productivas fuertemente endeudadas), ${ }^{26}$ promovería un movimiento mercantil creciente que aparecería reflejado en los diversos libros de la documentación alcabalatoria.

Sin embargo, en este caso, la totalidad del comercio fue igualado, incluidas las tiendas y los changarros de las localidades con comercio estable (Cuautla, Jonacatepec, Zacualpan, Ocuituco, Yecapixtla, Real de Huautla). Parecería que la centralización no provocó ningún cambio sustantivo en el sistema de recaudación. Pero esto no es totalmente exacto, ya que desde las reformas de Gálvez en 1765 , los remates en pública almoneda de las alcabalas se realizaban por periodos de cuatro o cinco años, lo cual dificultaba que la contabilidad de las mismas reflejase la evolución de

${ }^{25}$ Aquí hay que recordar que muchos de los intercambios reflejados en los montos totales de las igualas no eran realmente ventas donde interviniese circulante. Tal y como indican $J$. C. Grosso y J. C. Garavaglia: el dueño de la hacienda se iguala "en concepto de lo que vende a sus gañanes; es obvio que estamos aquí frente a un trueque de trabajo por mercancías sin que se acuda al uso del dinero sino en proporciones mínimas", Región, 1996, p. 123.

${ }^{26}$ Un estudio pormenorizado del proceso de endeudamiento de una hacienda azucarera de la zona lo tenemos en Wobeser, San Carlos, 1980. 


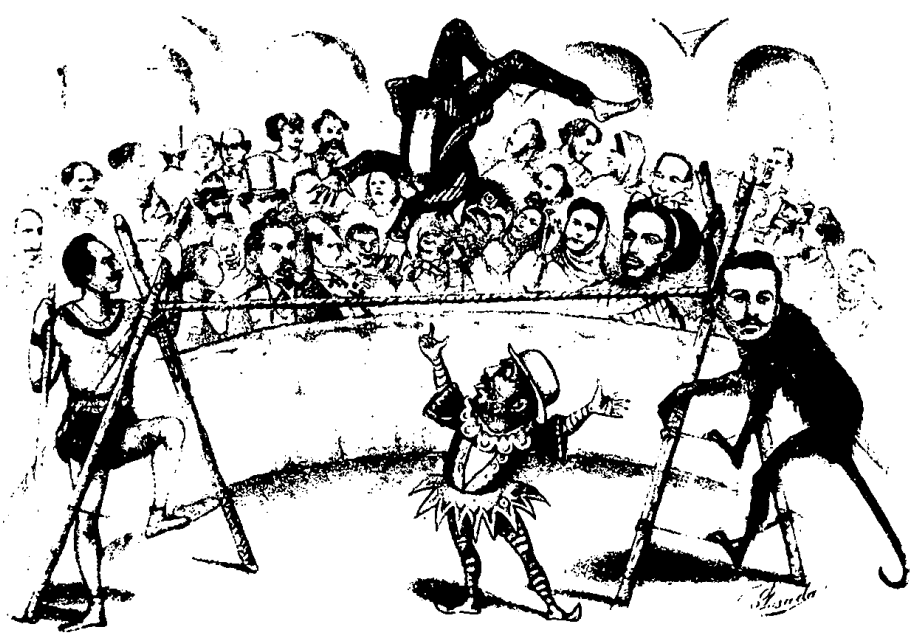

los intercambios mercantiles de la receptoría. A partir de 1776 , se podrían continuar celebrando igualas, pero sólo condicionales y por un periodo máximo de un año, lo cual impediría que hubiese un fuerte desfase entre fiscalidad y circulación mercantil. Además, pese a que los productos del viento y las introducciones de bienes de la tierra, Castilla y China, debían ser registrados puntualmente en la contabilidad anual, no podemos encontrar en la contabilidad de la renta de alcabalas, un indicador de la gran cantidad de insumos en circulación que eran necesarios para la explotación de los ranchos, los ingenios y las minas de la zona. ${ }^{27}$

${ }^{27}$ En relación con la actividad agrícola no pagaban alcabala "el fierro, acero, ganados y cualesquier otros utensilios que los hacendados
Por tanto, las igualas de Cuautla de Amilpas estarían mostrando únicamente la tendencia económica, en el mediano y largo plazo, de las principales unidades productivas (haciendas, minas y ranchos), en tanto que el movimiento mercantil generado en la receptoría a lo largo del periodo, dependería de la evolución de las actividades productivas allí desarrolladas.

Había un matiz importante: la producción dominante de Cuautla de Amilpas estaba altamente comercializada y monetarizada. El mercado del azúcar, especialmente el del azúcar blanca,

introducen en sus haciendas para su cultivo, beneficio y apero", Circular de la Dirección General de Alcabalas Foráneas del 28 de mayo de 1790 , y en relación con las minas, Circular de 28 de mayo de 1790 , véase Grosso y Garavaglia, Región, 1996, pp. 88-89. 
eran las clases altas del virreinato. Por tanto, la evolución de la renta de alcabalas de Cuautla de Amilpas refleja, parcialmente, una producción sometida a procesos de deflación (1780-1790, 1801-1810) e inflación (1791-1800, 1810-1820). ${ }^{28}$

El análisis de la relación entre el indulto del aguardiente de caña y su alcabala permite profundizar en los problemas de esta fuente, como instrumento de medición de la actividad económica, máxime cuando la producción dominante y comercializable de una receptoría de alcabalas tenía como destino mayoritario otros suelos alcabalatorios (véase gráfica 2). En ésta se puede apreciar claramente el contraste. Mientras que la evolución de la renta del indulto de fabricación del aguardiente de caña, enfocada a los mercados de México y Puebla, sí nos transmite efectivamente la producción de barriles que sale al mercado, la alcabala registrada en Cuautla de Amilpas únicamente contiene las ventas realizadas dentro del propio suelo alcabalatorio, con el añadido de ser un mercado de escasas dimensiones donde era fácil adquirir la bebida en pequeños chiringuitos ilegales a precios más baratos. De hecho hay una clara discordancia en los periodos, 1797 . 1805 y 1813-1816, entre producción y alcabala. Por tanto, hay que reiterar el carácter indirecto de unas alcabalas compuestas mayoritariamente con igualas, como indicador de la actividad económica de una zona. Con estos principios podemos descomponer la contextura y evolución de dichas igualas.

\footnotetext{
${ }^{28}$ Crespo, "Precios", 1995.
}

De la totalidad de los años aquí analizados hemos podido desglosar las igualas en 28 , es decir, en $67 \%$. Se han localizado seis libros de igualas (1777, $1783,1789,1798,1803$ y 1815$)$ correspondientes a estos años, que nos han permitido hacer un seguimiento de la composición y evolución interna de las mismas en los distintos periodos considerados en este trabajo, indicando que presentamos tanto la recaudación total, como la de igualas al $6 \%$ (véase gráfica 3).

Como ya indicamos, se aprecia el carácter predominante de las igualas en la composición de las alcabalas de la receptoría de Cuautla de Amilpas, al representar ésta, en promedio, $74 \%$ del total de la recaudación. Para apreciar el papel básico de las igualas dependientes de las haciendas y los ranchos hay que proceder a desglosarlas según su procedencia (véase cuadro 6 ). ${ }^{29}$

Podemos observar cómo las igualas de los purgares y tiendas de las haciendas y los ranchos pegujaleros representan, en promedio, $58 \%$ del total de ellas en Cuautla de Amilpas, procediendo el restante $42 \%$, de las tiendas y changarros de Cuautla, Huautla, Jonacatepec, Zacualpan y Yecapixtla. Este predominio de las igualas de las haciendas se intensificó durante el periodo insur-

\footnotetext{
${ }^{29}$ Hay que indicar que se ha intentado separar las ventas igualadas de los purgares (azúcar y miel) de las ventas realizadas a la población que habitaba en las haciendas (tiendas de haciendas), sin embargo entre 1777 y 1798 no ha sido posible realizarlo en su totalidad, lo cual nos ha obligado a introducir el rubro "purgar y tienda", dependiente de las haciendas de la receptoria.
} 
gente, elevándose su porcentaje a $81 \%$ del total.

En correspondencia con este cambio, presenciamos otro sustantivo en la proporción de los comerciantes que poseían tiendas y changarros: el de representar éstos en 1803 el $9 \%$ respecto a las tiendas, en el cuaderno de igualas de 1815 , donde vemos que alcanzan $36 \%$. Parecería que el gran comercio de la zona casi había sido eliminado, pasando muchas de las anteriores tiendas a la categoría de changarros. Es evidente que los conflictos bélicos supusieron problemas para la producción de las haciendas. En algunos de sus libros de cuentas (caso de Cuahuixtla) o en los libros de diezmos de 1820 , vemos cómo varias han cesado sus operaciones y sus tierras han sido arrendadas a campesinos, lo cual tuvo que afectar al tráfico mercantil de la receptoría; aunque también hay que interpretar esta medida como parte de la capacidad de resistencia ya aludida de los comerciantes y hacendados frente a los intereses de la Hacienda Real de obtener mayores ingresos. Los comerciantes continuaban igualados, pero con un costo inferior.

Finalmente, las igualas en la Receptoría de Cuautla de Amilpas nos permiten ver cómo hubo un proceso de ellos en las ventas de los comerciantes de la zona. Se constituyó un pequeño núcleo de ellos que acapararon las principales ventas. La mayoría de ellos eran propietarios de los purgares y las tiendas de las haciendas de Cuautla de Amilpas y su agregado de Jonacatepec (véase apéndice II y cuadro 7).

A lo largo del periodo destaca la polarización entre una mayoría de peque- ños comerciantes $(56 \%)$ que realizaba un comercio de menudeo, representando sus igualas $13 \%$ del total, y una minoría (15\%) que aportaron $51 \%$ de ellas y, por ende, de los intercambios. Estos elementos muestran el papel dominante de la hacienda azucarera y de los ranchos pegujaleros en la esfera de la circulación del territorio de lo que fue la alcaldía mayor de Cuautla de Amilpas y la villa de Jonacatepec.

\section{DiNÁMICA DE LA RECAUDACIÓN \\ DE ALCABALAS EN LA RECEPTORIA \\ DE CUAUTLA DE AMILPAS}

Conocida la estructura de unas alcabalas dominadas por una agricultura altamente comercializada, en la cual las igualas son su eje vertebrador, es preciso proceder a un análisis diacrónico que nos explique su evolución. El desglose de las cifras, así como la inclusión del periodo anterior a la centralización de la renta de alcabalas en 1776 y el periodo insurgente nos permiten evaluar más detenidamente los cambios acaecidos (véase gráfica 4).

Podemos constatar tres elementos principales a partir de esta gráfica. En primer lugar, aunque se ve una tendencia ascendente entre 1764 y 1776, no se puede detectar la evolución del mercado, ya que las alcabalas estaban empadronadas con un monto fijo anual por un periodo de cuatro o cinco años. En segundo lugar, se evidencia el éxito que supuso el paso del sistema de encabezamientos al de administración real. Comparando los 7045 pesos de la recaudación de 1776 con los 13752 pesos netos del primer año completo 
bajo el sistema de administración real, se observa cómo ésta se incrementó en 1778 en $95 \%$. En tercer lugar, se constatan los trastornos que ocasionó el movimiento independentista en la recaudación, máxime cuando Cuautla de Amilpas fue uno de los principales teatros de operaciones de las tropas realistas e insurgentes entre 1812 y 1813.

Sin embargo, partiendo de esta curva de recaudación bruta de alcabalas no se puede establecer la tendencia de la fiscalidad mercantil. Por necesidades económicas de la corona, se variaron los porcentajes de recaudación entre 1777 y $1820,{ }^{30}$ de forma que se tienen que desagregar dichas variaciones para poder observar realmente el curso de la recaudación. La ventaja que presentan las receptorías pequeñas, con administradores que cobraban un porcentaje de la recaudación, frente a las principales administraciones (Guadalajara, Puebla, Oaxaca, Bolaños, Cuernavaca, Durango, etc. hasta un total de 24) que aportaban un salario fijo, está en que en ellas se puede conocer la re-

${ }^{30} 6 \%$ entre 1777 y octubre de $1780 ; 8 \%$ entre 1780 y mayo de 1791 ; nuevamente $6 \%$ entre 1791 y mayo de 1794 para retornar a $8 \%$ entre 1794 y 1795 , y desde ese año y hasta el inicio de la insurgencia en 1811 el porcentaje volvió al $6 \%$ inicial. Entre 1811 y 1820 los porcentajes fueron: sobre el $6 \%$ de alcabala común, se estableció el 1 de enero de 1811, un aumento de $2 \%$ del préstamo patriótico, total $8 \%$. Por orden del 24 de diciembre de 1816, se aumentó $8 \%$ más sobre los efectos de aforo y $6 \%$ más de los efectos del viento, en sustitución de los impuestos de convoy y de extraordinario de guerra, quedando la recaudación así: $16 \%$ en efectos de aforo y $12 \%$ en efectos de viento, hasta el 9 de octubre de 1821, AGN, Histórico de Hacienda, leg. 117 , f. 398. caudación total bruta y neta al $6 \%$, dado que sus gastos de recaudación (los ingresos del administrador en este caso) eran únicamente de 10 o $12 \%$ (según el momento) del total recaudado al $6 \%$ (véase gráfica 5 ). ${ }^{31}$

El panorama cambia sobremanera para los dos momentos en que los aumentos de la tasa impositiva tuvieron una mayor duración: la década de los ochenta del siglo XviII, cuando la recaudación subió $8 \%$ con el objeto de sufragar parte de los gastos que ocasionaba la guerra con Inglaterra, y todo el periodo insurgente. Al desagregar las variaciones en las tasas, los crecimientos se convierten en estancamientos o francos descensos en el movimiento comercial sometido a fiscalización.

Sin embargo, existe otro problema. Pese a la mejora en la percepción de la dinámica de la recaudación de la renta de alcabalas, se mantiene el problema de las transacciones de bienes raíces. ${ }^{32}$ No se podía proceder a una simple sustracción de un porcentaje promedio, ya que su distribución no era

${ }^{31}$ En los casos que conservamos la recaudación desagregada de $2 \%$ y $8 \%$ de incremento y la tasa de $6 \%(1783,1786,1789$ y 1794, además de todo el periodo insurgente) hemos constatado que la diferencia entre los libros reales, resúmenes y la simple operación aritmética de sacar el $6 \%$ de la recaudación a partir del porcentaje de sueldo de los administradores nos arrojaba un error medio insignificante (0.34\%). Este simple procedimiento nos ha permitido reconstruir la curva de recaudación al $6 \%$.

${ }^{32} \mathrm{De}$ los 42 años que contemplamos en nuestro análisis (1778-1820), hemos podido desagregar las ventas de inmuebles en veinte de ellos $(48 \%)$ resultando que este rubro alcanza $9.2 \%$ del total de intercambios registrados en los libros de alcabalas. 
homogénea e incluso en determinados años fue una parte fundamental de los ingresos de la receptoría. ${ }^{33}$ Con el fin de obtener una visión lo más clara posible de la tendencia de la recaudación de alcabalas al $6 \%$, se optó por construir la tendencia central de la serie a partir de su transformación en una serie logarítmica, ${ }^{34}$ con el siguiente resultado (véase gráfica 6 ).

La evolución de la recaudación presenta una tendencia ascendente entre 1778 y 1810 , con una tasa de crecimiento anual de $1.47 \%$. A partir de 1811 (véase gráfica 5), la recaudación decrece hasta el mínimo en 1812, estabilizándose en una recaudación anual media de 9000 pesos. El incremento de 1819 es totalmente excepcional y no tiene que ver con el movimiento mercantil, sino con la venta de inmuebles.

Para poder explicar la evolución de la renta de alcabalas en Cuautla de Amilpas se ha de acudir, evidentemente, al sector que determinó toda la vida económica del valle de Amilpas y las Tlalnaguas: la producción de azúcar y miel, y la de aguardiente como su derivado.

Si bien la evolución del conjunto de la economía novohispana estuvo determinada por los ritmos de la producción dominante $e^{35}$ a saber, la explota-

${ }^{33}$ Así, en 1787 alcanzo $25 \%$ del total de las alcabalas de Cuautla de Amilpas; en 1811, 46\%, y en $1819,69 \%$. AGN, Real Hacienda-Indiferente, Aduanas foráneas y Alcabalas, vol. 317.

${ }^{34}$ Floud, Métodos, 1982, pp. 122-124.

${ }^{35}$ Acudimos a este concepto retomado por C. Sempat Assadourian de K. Marx, según el cual: "En todas las formas de sociedad existe una determinada producción que asigna a todas su correspondiente rango e influencia", Assadourian, Organización, 1998, p. 20. ción de las minas y la elaboración de sus productos, en cada región del territorio virreinal se desarrollaron producciones con cierto grado de autonomía en el corto plazo. La explicación de la recaudación de las alcabalas de la re. ceptoría de Cuautla de Amilpas ha de remitirse, necesariamente, a la producción generada por los trapiches e ingenios azucareros de la zona. Una producción que se insertaba en la economía alimentaria del virreinato dentro del sector de consumo, exportando hacia las ciudades de México y Puebla la mayoría del azúcar y del aguardiente fabricado.

Dado que apenas se conservan libros de cargo y data de las principales haciendas de la zona, la única fuente que nos puede aproximar a una evolución de la producción en la receptoría de Cuautla de Amilpas son los diezmos. Por ella constatamos cómo la tendencia de la producción azucarera de la región de Cuernavaca-Cuautla de Amilpas fue creciente durante la década de los ochenta del siglo xviI y la primera del siglo XIX. Así en 1785-1789 se elaboraron 471970 panes de azúcar; entre 1790-1794, 515488 y entre 1795-1799, 619 596, para alcanzar la cifra de 772793 en el quinquenio 1800 $1804,{ }^{36}$ lo cual representó un impor-

\footnotetext{
${ }^{36}$ Estas cifras, aparecidas en un folleto impreso en 1822, son de panes de azúcar labrados en el arzobispado de México, es decir, casi exclusivamente el conjunto de las ticrras que hoy forman el estado de Morelos (las alcaldías mayores de Cuernavaca y Cuautla de Amilpas), ya que las otras grandes zonas productoras (Orizaba, Michoacán, Córdoba o Izúcar) se encontraban en otros distritos eclesiásticos. AGN, Hos-
} 
tante crecimiento anual en la producción del orden de 2.6 por ciento.

A pesar de la tendencia creciente en la fiscalidad mercantil y decimal de la región a lo largo del periodo 1776-1810, se puede establecer una serie de etapas con características propias. En el caso del periodo insurgente, tenemos una evolución distinta. Con objeto de localizar dichas etapas hemos trasladado la curva bruta de recaudación al $6 \%$ a números índices, lo cual nos muestra tres grandes etapas, en la recaudación de alcabalas de la receptoría de Cuautla de Amilpas. ${ }^{37}$

\section{8-1790, estancamiento $y$ regresión}

El primer periodo que abarca de $\mathbf{1 7 7 8}$ a 1790 , con un índice medio de 90 , está caracterizado por el estancamiento y la regresión en el movimiento mercantil, compensados parcialmente por el aumento de $2 \%$ en la tasa de recaudación. Esta evolución de la renta de alcabalas en la Receptoría de Cuautla de Amilpas, va pareja con la evolución negativa de los ingresos ordinarios en la

pital de Jesús, leg. 219 , exp. 2 (citado por Barret, "Morelos", 1976, pp. 162-164).

${ }^{37}$ Apéndice 11. Al establecer la base de los números índice en las alcabalas se presentó el problema de las transacciones de bienes raíces que, como ya vimos, no representan un volumen destacable de la recaudación pero que, en determinados años, distorsionaban claramente la evolución del movimiento mercantil. Así fue en el primer año completo de recaudación de la serie (1778). Con el objetivo de ponderar dichas ventas se decidió establecer como base el promedio de la recaudación (1778-1820). fiscalidad virreinal ${ }^{38}$ Casi desde el inicio de la centralización en 1778 , las alcabalas presentaron una clara tendencia descendente en la totalidad de las receptorías foráneas. ${ }^{39}$

Si bien la fiscalidad decimal de Cuau. tla de Amilpas registra levemente la crisis agrícola de $1785-1786,{ }^{40}$ dado el carácter irrigado de la agricultura de las haciendas azucareras de la zona, ${ }^{41}$ las alcabalas de dichos años no lo hacen. El hecho de que los hacendados azucareros, soportes básicos de la fiscalidad de esta receptoría, estuviesen igualados, y de que su producción, y por tanto sus ventas, no estuviese tan sometida a la meteorología, explicarían esta situación. Sin embargo, el ascenso de las alcabalas de 1787 (índice 112) sí es indicador de alguna de las consecuencias de las crisis agrícolas: ${ }^{42}$ endeudamiento, quiebra y venta de bienes raíces. En palabras del superintendente de la Aduana de México al segundo conde de Revillagigedo:

${ }^{38}$ Pérez, "Beneficiarios", 1991, pp. 228-230.

${ }^{39}$ En el conjunto de las aduanas foráncas el descenso fue claro. Asi entre 1776-1780, la recaudación total fue de 2583152 pesos, mientras que entre $1781-1785$, el total recaudado fue inferior al volumen de ingresos del anterior quinquenio, 2082534 pesos. Un descenso que sólo pudo ser paliado, en parte, por el aumento del $2 \%$, lo cual significó que la recaudación alcanzase los 2856024 pesos. "Expedientes sobre el aumento del derecho de alcabala durante la guerra y sus incidencias", 1796, AGN, México, leg. 2097.

${ }^{40}$ Archivo del Cabildo Metropolitano (en adelante ACM), Clavería, libros 62, 63 y 64, y AGI, México, leg. 2728. Florescano, Fuentes, 1981, vol. II, p. 838 .

41 Scharrer, Azúcar, 1997, pp. 70-77.

42 El concepto de crisis agricola, en un territorio como Cuautla de Amilpas dificilmente 
el exceso que suele tener el mismo ramo [de alcabalas] en algún año, sería error atribuirlo precisamente a mayor giro, pues dimana con frecuencia que los ingresos no trascienden ni provienen de él $[\ldots]$ insinuando limitadamente a $V$. E. que las ventas de las haciendas de campo, las de casas, las imposiciones de varias calidades de censos, los traspasos y otros contratos motivan la alcabala, que de ninguna manera procede, $y$ al contrario, son a veces indicación positiva, en el curso mercantil, de abatimiento. ${ }^{43}$

Esto mismo ocurrió en Cuautla de Amilpas en 1787: la venta de la hacienda de Santiago Tenextepango, por un total de 66500 pesos, causó 3879 pesos de alcabala, es decir, $25 \%$ de la recaudación anual al $6 \%$. Dichas ventas eran la muestra de que la economía campesina y la hacienda azucarera estaban, hasta cierto punto, disociadas.

Si bien hemos constatado que la renta de alcabalas de Cuautla de Amilpas descendió en consonancia con los ingresos fiscales del virreinato, una relación más directa con esta tendencia descendente la encontramos en el comportamiento de los precios del azúcar de la década de los años ochenta del

se puede entender de forma unívoca, dado que convivían, al menos, dos estructuras agrarias: la campesina indígena, con base en el maíz, y la de las haciendas azucareras. En la primera, la crisis estaba vinculada al ciclo meteorológico (es el caso de 1785-1786), mientras que en la segunda, la crisis era resultado de una sobreproducción relativa respecto al consumo. Véase Crespo, "Precios", 1995, pp. 112-113.

${ }^{43}$ AGN, "Informe de M. Páez de la Cadena, superintendente de la Aduana de México, al conde de Revillagigedo", de 13 de enero de 1792, Alcabalas, vol. 543 , fs. 63 y 67-70. siglo xvil. Tal y como indicó Horacio Crespo, a pesar de existir una tendencia general al alza de dichos precios entre 1770-1832, en esa década hubo una contracción de los mismos, pasando de aproximadamente quince reales por arroba en 1770 a unos once reales hacia 1790, es decir, un descenso de casi 26\%. De hecho, 1790 fue el fondo de la recesión en la recaudación de alcabalas de Cuautla de Amilpas. Una década de crisis que afectó al mercado del azúcar $y$, por tanto, a la actividad mercantil de toda la zona, en tanto que era una zona dependiente de dicho mercado.

\section{1-1810: crecimiento}

Los 20 años que abarcan la última década del siglo XviII y la primera del siglo XIX significaron para las alcabalas de Cuautla de Amilpas un cambio en la tendencia: del estancamiento y la recesión se pasó a una situación de crecimiento, con un índice medio de 118 en la recaudación.

Una vez más, la tendencia es semejante en relación con los ingresos fiscales novohispanos, incluso con la misma secuencia: dentro de una tendencia general alcista, ascenso claro entre 17911800 y a partir de aquí, un descenso hasta llegar a 1810, apenas interrumpido a mediados de la década. ${ }^{44}$

En el caso concreto de las alcabalas de Cuautla de Amilpas, difícilmente podemos pretender asimilar este crecimiento mercantil a las mejoras acaecidas tras el cese de las hostilidades con

${ }^{44}$ Pérez, "Beneficiarios", 1991, pp. 232-239. 
Inglaterra, a las ventajas que reportaba el sistema libre imperial, ampliado a Nueva España en $1789,{ }^{45}$ o al desarrollo del comercio neutral, si no es de una forma muy indirecta y lejana. El aumento en la recaudación, así como su intensidad, fue motivado por un proceso inflacionario del precio del azúcar a lo largo de los años noventa y la primera década del siglo XIX. Aunque este aumento no fue muy relevante (0.3\% anual durante casi medio siglo), ${ }^{46}$ significó una posibilidad de beneficio creciente que impulsó a la producción, lo cual acabaría reflejándose en las igualas de la receptoría. ${ }^{47}$

Este incremento en la producción y el precio del azúcar tuvo causas varias que van desde la hipótesis, ya planteada, de un proceso inflacionario general a finales de la centuria que acabó arrastrando los precios azucareros, la desaparición de Haití como principal exportador mundial de azúcar tras la rebelión de los esclavos en 1791 y la desaparición de unidades productoras 284.

${ }^{45}$ Kuethe, "Desregulación", 1991, pp. 283-

4613.9 reales/arroba en promedio (17721790); 15.5 (1791-1808); 16.6 (1809-1823). Crespo, "Precios", 1995, p. 114.

${ }^{47}$ Esta inflación de los precios del azúcar en los mercados de consumo, con unas unidades productivas tendientes a reducir costos mediante el control de las distintas fases de la producción (desde la producción de la caña hasta su transformación manufacturera) y los recursos necesarios en dicha producción (mano de obra residente y temporera, tierra, agua, leña, ganado, etc.) representó un estímulo al proceso productivo de los hacendados azucareros. Una tendencia creciente en la producción que acabaría siendo fuertemente impulsada tras la legalización de la fabricación del aguardiente de caña en 1796. no rentables en el periodo anterior a 1770 , todo lo cual creó una oferta declinante. Sin embargo, la legalización de la producción y la circulación del aguardiente de caña en 1796 tuvieron un efecto inmediato y directo sobre la recaudación alcabalatoria. ${ }^{48}$

Tal y como se indicaba en el artículo segundo del reglamento para la fabricación y venta del aguardiente de caña, ${ }^{49}$ de 9 de diciembre de 1796, en Cuautla de Amilpas, junto con Córdoba, Orizaba, Izúcar y Cuernavaca, se permitía la fabricación y venta de dicho producto tras el preceptivo pago del indulto por su producción (seis pesos por barril a pie de fábrica) y el pago de la alcabala. La respuesta de los productores no se hizo esperar. En 1797, primer año de fabricación legal, se produjeron en Cuautla de Amilpas 3530 barriles, que aportaron por derechos de indulto a la Real Hacienda, 21177 pesos. En 1800 el número de barriles ya llegaba a 5643 , para alcanzar la cifra de 6706 en 1810, es decir, un crecimiento anual del orden de $5.1 \%$. En menos de tres quinquenios, la producción casi se había duplicado.

\footnotetext{
${ }^{48}$ Crespo, "Precios", 1995, p. 110; Hernández, Aguardiente, 1974; Lozano, Chiringuito, 1995. En el caso de la rebelión de la antigua colonia francesa y sus efectos sobre la producción y el comercio novohispano de azúcar, el folleto ya citado, de 1822, indica: "Pero su mayor ade. lantamiento (el cultivo de la caña de azúcar) reconoció por principio la guerra civil de Santo Domingo y la destrucción de los trapiches franceses. Con este motivo, por el tiempo que escribía el barón de Humboldt, la exportación de azúcar por el puerto de Veracruz era de más de 500000 arrobas".

${ }^{49}$ AGI, México, leg. 2330 (reproducido por Lozano, Cbiringuito, 1995).
} 


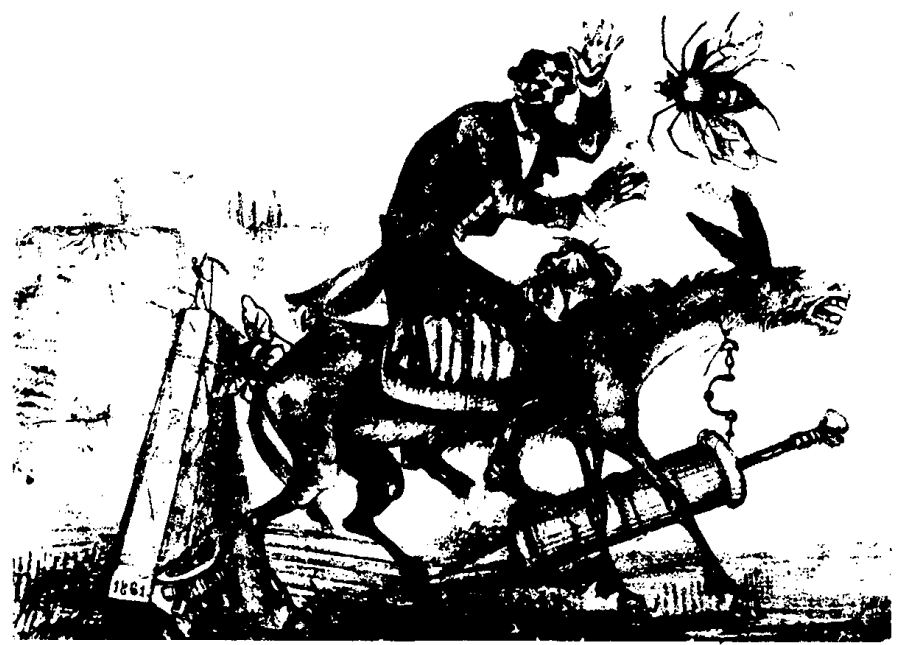

Es interesante observar cómo el aumento de la producción de panes de azúcar entre 1785 y 1804 encontró su complemento en la legalización del aguardiente de caña. Con anterioridad a 1797, la creciente producción de azúcar generaba cantidades cada vez mayores de mieles de baja calidad, las cuales sólo servían para fabricar a precios muy bajos piloncillo y otros dulces. Tras la legalización del aguardiente de caña, estas mieles encontraron una salida rentable, dado que constituían la materia prima de dicha bebida. De tener casi una consideración de "residuo", pasaron a ser un rubro fundamental en las haciendas azucareras (véase gráfica 7$).^{50}$

${ }^{50}$ Es evidente que, con anterioridad a 1796, se producía en Nueva España aguardiente de

En el caso de la receptoría de alcabalas de Cuautla de Amilpas, se puede ver la similar evolución de la producción de barriles de aguardiente de caña (recuérdese que el indulto por producir aguardiente ilegal de caña hasta 1812 era de seis pesos por barril, por tanto es un impuesto que nos está aportando los volúmenes de la producción legal) y la fiscalidad mercantil, existiendo leves discordancias en 1798 y 1810.

Sin embargo, esta gráfica nos vuelve a evidenciar la pugna entre los administradores de alcabalas y los produc-

caña (la relación de expedientes judiciales aportada por Lozano es un indicador claro), pero lógicamente esta situación de clandestinidad impedía que la fabricación en pequeños alambiques ilegales tuviese una influencia considerable en la evolución de la producción de mieles y sus precios. 
tores de azúcar y aguardiente de la receptoría, en especial en el periodo posterior a 1805. Hasta ese año, tanto la evolución como la magnitud de las tendencias de la renta de alcabalas y del indulto del aguardiente fueron semejantes; mientras que a partir de 1805 no hay una correlación entre la magnitud del crecimiento del indulto del aguardiente de caña y el menor crecimiento experimentado por la fiscalidad mercantil. Si contrastamos esta discrepancia de magnitudes con la gráfica 3 , se puede entender la diferencia. Tras el conflicto, ya analizado, sobre el cambio en el sistemá de las igualas desarrollado entre 1805-1806, se comprueba cómo las igualas prácticamente permanecieron estancadas entre 1805 y 1810 , lo cual motivó que hubiese leves diferencias en la recaudación total de alcabalas de dichos años. El importante aumento en la producción de aguardiente no quedó reflejado en las alcabalas. El éxito en mantener el sistema de igualas, tal y como se configuró en 1777 , y su práctica congelación durante el sexenio anterior a 1811, significó un aumento considerable en las ganancias de los hacendados y productores de aguardiente de la Receptoría de Cuautla de Amilpas. Este panorama se vio severamente alterado por el estallido del proceso independentista, el cual vino a dislocar el difícil equilibrio alcanzado en la zona de tierra caliente de esta receptoría.

\section{1-1820: ¿crisis? e inflación}

Ya vimos (véase gráfica 5) la gran discrepancia que existió entre la recauda- ción bruta total y la recaudación bruta al $6 \%$ en la receptoría de Cuautla de Amilpas. Más que una recesión (en 1812 la recaudación cayó a 1104 pesos) la recaudación bruta total mostraba una etapa de estancamiento en niveles próximos a los de principios de la década de los noventa. Incluso 1818 y 1819 serían claramente superiores. De hecho, en esa receptoría los 31405 pesos de 1819 fueron la recaudación de alcabalas más alta de todo el periodo colonial.

Esta situación era semejante a la de los ingresos netos de la Real Hacienda de Nueva España durante el periodo insurgente, la cual nos muestra un periodo en que la fiscalidad se apartaba peligrosamente de la evolución de la producción y de su comercialización. Tal y como indicó Pedro Pérez, la corona aumentó la presión fiscal, incrementando viejos arbitrios o creando nuevos, como un último medio para ampliar los recursos extraordinarios, una vez que los movimientos independentistas se habían iniciado. ${ }^{51}$

Hemos podido comprobar cómo la construcción de la curva de recaudación bruta al $6 \%$ nos aportaba un panorama totalmente diferente. Con un índice de 73 de recaudación media, el estancamiento del periodo 1811-1820 se transforma en una tendencia decreciente en el movimiento mercantil, salvo en 1819 (véase gráfica 8).

Observamos cómo la década de 1810-1820 presenció un movimiento descendente en el movimiento mer-

${ }^{51}$ Pérez, Beneficiarios, 1991, pp. 236-239 y 245-247. 
cantil sometido a fiscalización, con una tasa anual próxima a $-6.6 \%$. El problema de este periodo consiste en explicar esta gran disparidad en los volúmenes de recaudación, ya que en el periodo 1780-1795 esta diferencia entre la recaudación al $6 \%$ y el $8 \%$ era de $23.8 \%$, mientras que entre 1810-1820, esta diferencia se elevó a cerca de 60 por ciento.

Evidentemente, la explicación inmediata la encontramos en los aumentos de la tasa realizados entre 1811 y 1820 que, como ya indicamos, llegaron a $16 \%$ en los bienes de aforo y a $12 \%$ en los del viento en 1816 y hasta 1821. Sin embargo, ¿cómo explicar que comerciantes y productores de las haciendas azucareras y ranchos soportasen pagar más por concepto de alcabalas, entre 100 y $130 \%$, en un momento de crisis bélica? Y, por otra parte, cabe preguntar: ¿existió efectivamente una depresión?

En principio, las igualas de Cuautla de Amilpas nos muestran un gran cambio entre 1810-1820. Su volumen respecto del total descendió ( $68 \%$ entre 1778-1795, $75 \%$ entre $1796-1810,58 \%$ entre 1811-1820), aumentando el rubro de ventas al menudeo (viento) y las de bienes raíces, que como ya vimos tienen más que ver con un periodo de crisis que de pujanza económica. ${ }^{52}$ Sin embargo, el sustento de dichas igualas pasó a ser, de forma abrumadora, la aportación realizada por

\footnotetext{
52 En este caso, 1819 es un año paradigmático. La venta de una de las principales haciendas de la jurisdicción, la de Casasano, por un valor de 265000 pesos causando una alcabala al 6\% de 15900 pesos, es un claro ejemplo, AGN, Alcabalas, vol. 317 .
}

los propietarios de los purgares y las tiendas de las haciendas azucareras, llegando al $77 \%$ del total.

Los hacendados azucareros vieron los efectos destructivos producidos por la insurgencia, en especial durante el sitio de Cuautla y las sucesivas operaciones bélicas entre 1811 y 1813. Muchas dejaron de producir. ${ }^{53}$ El recaudador de alcabalas de Cuautla, Anselmo Rivera, indicaba en 1813 al director general de alcabalas:

Señor director general $[\ldots]$, los seis meses segundos del año de 1812 sólo comprenden la renta de alcabalas de Cuautla reconocida en su mayor parte, pues en lo anterior estuvo ocupado por los insurgentes al mando del cura Morelos. ${ }^{54}$

La insurgencia produjo la paralización de las actividades productivas $\mathrm{y}$, en su contra, la acción de los hacendados fue clara. Pagar más implicaba asegurarse la protección de las tropas realistas que, una vez levantado el sitio de Cuautla, permanecieron en Cuernava-

\footnotetext{
${ }^{53}$ Un ejemplo destacable es la situación de la principal hacienda de la zona en la época, San Pedro Mártir, alias Cuahuixtla. En uno de los pocos libros de cargo y data de las haciendas azucareras de Cuautla de Amilpas conservado, leemos: "El 30 de diciembre de 1811 [...] aquí empezó la insurrección de Cuautla, y el trastorno también de esta hacienda", y en la semana del 24 de febrero de 1812, leemos: "En esta semana comenzaron los ataques por la tropa del rey, y el sitio formal de Cuautla. No se volvió a labrar ningún pan de azúcar y por eso se corta aquí la cuenta." AGN, Bienes Nacionales, vol. 1066, exp. 3.

${ }^{54}$ AGN, Aduanas Foráneas, Cuautla de Amilpas, Real Hacienda, Indiferente (1813).
} 
ca y Cuautla de Amilpas. Es sintomático que importantes datas de las cuentas de alcabalas y aguardiente de caña de la época fuesen a parar a las tropas asentadas en dichos lugares. ${ }^{55}$

Pero además, estos pagos se pudieron soportar en tanto que las igualas de los hacendados quedaron congeladas en un nivel inferior a 1810 con una tendencia decreciente. Esto no nos tiene que hacer pensar en una época de escasos beneficios para los hacendados. Al contrario, las expectativas de negocio crecieron de forma considerable durante el periodo 1811-1820. En palabras de Horacio Crespo:

El estallido del movimiento insurgente y las consecuencias de la guerra que afectó a importantes zonas azucareras, como los valles de Cuernavaca y Cuautla, y la región de Córdoba y Jalapa en Veracruz, produjo una importante reducción de la producción, y por ende de la oferta, en un momento en que las exportaciones entraban en un franco momento de declinación. De esta manera, pudo mantenerse durante la segunda y tercera del siglo Xxx, el equilibrio necesario sobre el que se basó la tendencia de los precios al alza. ${ }^{56}$

De hecho el precio medio de una arroba de azúcar en 1810 era, aproximadamente, de trece reales, mientras que a finales de la colonia, en 1820 , superaba los 16. Así, la reducción en la producción y el aumento en los costos a través de las diversas imposiciones,

55 Ibid. (1813, 1814 y 1815). Para ver el creciente peso militar en la hacienda durante la insurgencia, véase Jáuregui, Real, 1999.

${ }^{56}$ Crespo, "Precios", 1995, pp. 110-111 y 121. fue compensada parcialmente por el proceso inflacionario generado durante el conflicto bélico y por el mejor trato fiscal obtenido (evolución de las igualas) por los hacendados de Cuautla de Amilpas, de parte de una Real Hacienda ávida de numerario. Se imponía, una vez más, el peso de los productores sobre la administración virreinal, lo cual desdibuja, en algo, la imagen de una receptoría sometida a un proceso de depresión en su evolución económica durante el periodo insurgente.

\section{CONSIDERACIONES FINALES}

El estudio de las alcabalas de la Receptoría de Cuautla de Amilpas, situada en un marco rural donde se desarrolló una de las agriculturas más dinámicas e insertas en los circuitos comerciales, pone de manifiesto un problema: el de analizar los mercados, siquiera los intrarregionales, a partir de unas alcabalas compuestas mayoritariamente por las igualas.

Aunque en el conjunto novohispano este rubro apenas representó $10.4 \%$, en ciertos espacios fue el elemento clave de su estructura, con el problema añadido de que, tal y como se configuraron, implicó la continuidad con el sistema de recaudación existente con anterioridad a la centralización de 1776 , al englobar las igualas a productores y comerciantes. Este sistema benefició claramente al polo de productores y comerciantes frente a la Hacienda virreinal. Habría que ampliar los estudios sobre las receptorías donde la iguala fuese el elemento central para poder 
ponderar la representatividad de este estudio.

Asimismo, hemos constatado la importancia de construir series lo más homogéneas posibles con el objeto de establecer la evolución del movimiento mercantil sometido a fiscalización, para lo cual se han aportado ciertos elementos metodológicos (construcción de la curva bruta y neta al 6\%) que, en principio, tendrían validez para casi dos tercios de las receptorías, ya que tenían administradores cuyos ingresos procedían de un porcentaje de la recaudación.

El análisis realizado nos muestra la existencia de tres núcleos mercantiles en la Receptoría de Cuautla de Amilpas. En primer lugar estaba el formado por las tiendas y purgares de las haciendas azucareras, que realizó las principales ventas durante todo el periodo. Estas entidades atendieron a diversos consumidores: a la población residente y temporera que laboraba en dichos núcleos productivos (era el caso de las tiendas) y cubriendo las partidas de azúcar y miel que, en una proporción muy pequeña, se vendían en la propia receptoría, en especial en las localidades próximas. Estamos hablando de las calidades más bajas de azúcar, en especial panocha y piloncillo (como vimos los panes de azúcar tenían en México y Puebla su mercado); la miel que se vendió a los fabricantes de aguardiente de caña instalados legalmente en la receptoría a partir de $\mathbf{1 7 9 6 ,}$ y las ventas realizadas a mercaderes viandantes que dejaban productos en la receptoría (tierra y Castilla), y que se cargaban de partidas de azúcar, aguardiente y miel, para vender en otros sue- los alcabalatorios (era el caso de los purgares).

Un segundo núcleo estaría constituido por el comercio estable en manos de criollos de las distintas localidades de la receptoría, en especial Cuautla, el real de Huautla, Jonacatepec, Zacualpan y Yecapixtla. Encontramos comerciantes cuyas ventas en promedio superaban los 1600 pesos anuales. Estas tiendas atendían y controlaban los intercambios de dichos pueblos. En el caso del real de Huautla la situación sería un poco más compleja, dado que algunos de los principales comerciantes del real eran mineros, de forma que su comportamiento era más semejante al de los hacendados azucareros, quienes también instalaron tiendas en sus propiedades.

Finalmente, se localizaba un grupo de pequeños mercaderes indígenas y de tendajos en manos de criollos y mestizos que realizaban un gran número de transacciones, aunque de escaso valor, aproximadamente $4 \%$ del total de las ventas. Su comercio atendía las necesidades básicas de la población trabajadora residente en los pueblos de las cabeceras, pero sobre todo, de los pueblos de indios de la receptoría, con ventas centradas en productos tales como el maíz, la sal, el chile, los frijoles, la ropa de la tierra o los zapatos.

Así pues, el papel predominante de las haciendas azucareras en el territorio compuesto por las alcaldías mayores de Cuernavaca y Cuautla de Amilpas, no quedaría limitado al ámbito de la producción, sino que habría dominado también el de la circulación. Finalmente, este trabajo pone de manifiesto la necesidad de proceder a un estudio 
de las receptorías pertenecientes a la administración foránea de México y relacionadas con la Aduana de la ciudad de México.

\section{ARCHIVOS \\ ACM Archivo del Cabildo Metropolitano del Arzobispado de México \\ AGI Archivo General de Indias de Sevilla \\ AGN Archivo General de la Nación de México}

\section{Bibliografía}

-Alvarado Gómez, A. A., Comercio interno en la Nueva España. El abasto en la ciu. dad de Guanajuato, 1777-1810, INAH, México, 1995.

-Assadourian, C. S., "La organización económica del sistema colonial" en J. Silva Riquer y J. López Martínez (coords.), Mercados internos en México. Siglos XVIII-XIX, Instituto Mora, México, 1998.

-Barrett, W., "Morelos and its sugar industry in the late eighteenth century" en I. Altman y J. Lockhart, Provinces of early Mexico. Variants of spanish american regional evolution, UCLA, Los Ángeles, 1976.

-Crespo, H., "Los precios del azúcar en Nueva España: tendencias seculares y comportamiento cíclico" en V. García Acosta, (coord.), Los precios de alimentos y manufacturas novobispanos, Comité Mexicano de Ciencias Históricas/CIESAS/Instituto de Investigaciones Históricas-UNAM/Instituto Mora, México, 1995.

-Florescano, E. (comp.), Fuentes para la bistoria de la crisis agricola de 1785 . 1786, Archivo General de la Nación, México, 1981, 2 vols.

-Floud, R., Métodos cuantitativos para bistoriadores, Alianza Universidad, Madrid, 1982.
-Garavaglia, J. C. y J. C. Grosso, Las alcabalas novobispanas (1776-1821), Archivo General de la Nación/Banca Cremi, México, 1987.

- "Estado borbónico y presión fiscal en la Nueva España, 1750-1821" en Antonio Annino et al. (comps.), América Latina dallo Stato coloniale allo Stato nazione, Franco Angeli, Turín, 1987, vol. 1 .

"Marchands, hacendados et paysans a Tepeaca. Un marché local mexicain a la fin du xville. siecle", Annales $E S C$, vol. 44, núm. 3, mayo-junio de 1989. Puebla desde una perspectiva microbistórica. Tepeaca y su entorno agrario (1740-1870), Ed. Claves Latinoamericanas/ICSYH-UAP, IEHS-UNICEN, México, 1994.

"La participación indígena en la economía colonial: reflexiones desde una perspectiva regional (Puebla a fines del siglo XVIII)", Congreso Internacional de la ADHILAC, Querétaro, 1994.

LLa región de Puebla y la economia novobispana, Instituto Mora/ Universidad de Puebla, México, 1996.

-Gerhard, Peter, Geografía bistórica de la Nueva España, 1519-1821, UNAM, México, 1986.

-Hernández Palomo, J. J., El aguar. diente de caña en México (1724-1810), Escuela de Estudios Hispano-Americanos, Sevilla, 1974.

-Ibarra, A., "Mercado urbano y mercado regional en Guadalajara, 1790-1811: tendencias cuantitativas de la renta de alcabalas" en J. Silva, J. C. Grosso y C. Yuste (comps.), Circuitos mercantiles y mercados en Latinoamérica. Siglos XVIII-XIX, Instituto Mora/Instituto de Investigaciones Históricas-unam, México, 1995.

-Jáuregui, L. A., La Real Hacienda de Nueva España, Facultad de economíaUNAM, México, 1999.

-Kuethe, A. L., "La desregulación comercial y la reforma imperial en la época 
de Carlos III: los casos de Nueva España y Cuba", Historia Mexicana, El Colegio de México, vol. xII, núm. 2, 1991, México.

-Lozano Armendares, T, El cbiringuito vindicado. El contrabando de aguardiente de caña y la política colonial, UNAM, México, 1995.

-Marichal, Carlos, "Las guerras imperiales y los préstamos novohispanos, 17811804", Historia Mexicana, vol. xxxıx, núm. 4, 1990.

-Mentz, B. von, Pueblos de indios, mulatos y mestizos. 1770-1870, CIESAS, México, 1988.

Trabajo, sujeción y liber-

tad en el centro de la Nueva España, Porrúa/CIESAS, México, 1999.

-Moreno Toscano, A., "Economía regional y urbanización: tres ejemplos de relación entre ciudades y regiones en Nueva España a finales del siglo Xviı" en AA.VV., Urbanización y proceso social en América, Instituto de Estudios Peruanos, Lima, 1972.

-Pastor, R., "La alcabala como fuente para la historia económica y social de la Nueva España", Historia Mexicana, El Colegio de México, vol. xxvil, núm. 1, 1977, México.

-Pérez Herrero, P., "Los beneficiarios del reformismo borbónico: metrópoli versus elites novohispanas", Historia Mexicana, El Colegio de México, vol. Xlı, núm. 2, 1991, México.
-Sánchez Santiró, E., "Población, espacio y recursos en la alcaldía de Tetela del Volcán y el corregimiento de Ocuituco (1743-1826)" en El norte de Morelos, ¿Una región?, INAH/CRIM/UNAM, 1998.

- "Fiscalidad y reformismo borbónico: la centralización de la renta de alcabalas en la Receptoría de Cuautla de Amilpas (1764-1780)" en Morelos. Historia y crónica (en prensa).

-Scharrer Tamm, B., Azúcar y trabajo. Tecnología de los siglos XVII y XVII en el actual estado de Morelos, CiESAS/Porrúa/ ICM, México, 1997.

-Silva Riquer, J., La administración de alcabalas y pulques de Micboacán, 17761821, Instituto Mora, México, 1993.

-Smith, R. S., "Sales taxes in New Spain, 1575-1770", Hispanic American Historical Review, vol. XxvıI, núm. 1, 1948.

-Toledano Vergara, M. C., Tepalcingo, su bistoria y sus tradiciones, Gobierno del Estado de Morelos/PaCMyC, 1996.

-Wobeser, G. von, San Carlos Borromeo. Endeudamiento de una bacienda colonial (1608-1729), Instituto de Investigaciones Históricas-UNAM, México, 1980.

- "Relaciones entre los hacendados de Cuernavaca-Cuautla y los comerciantes de México y Puebla. Siglos xvi y XVII" en La ciudad y el campo en la bistoria de México, UNAM, México, 1992, vol. II. 


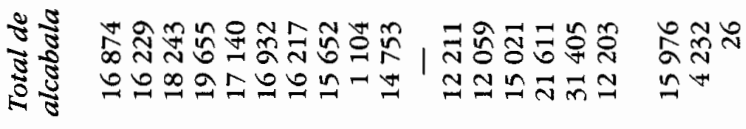

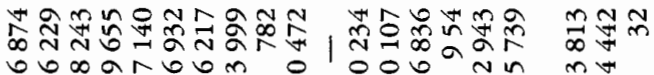

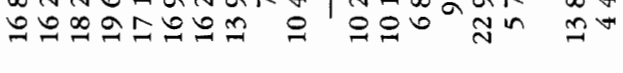

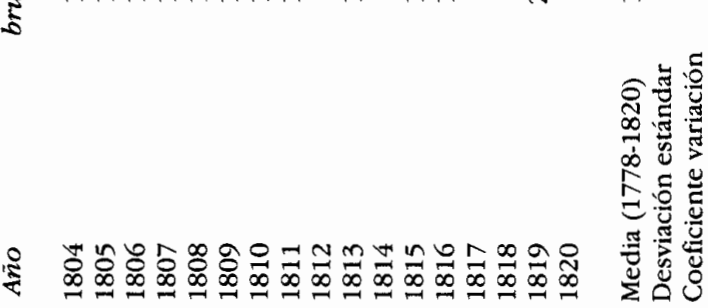

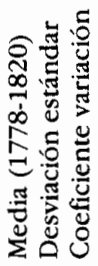

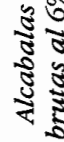

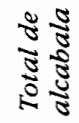

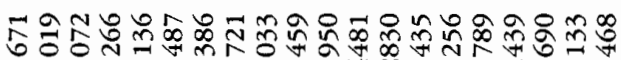

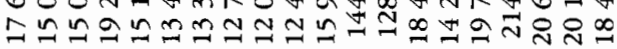

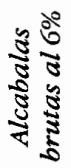

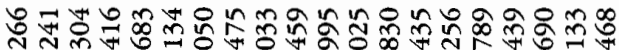


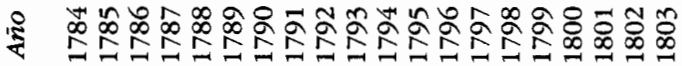

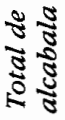

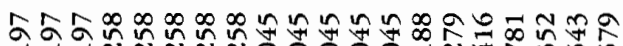
HW

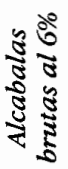

ลิ人ล W W

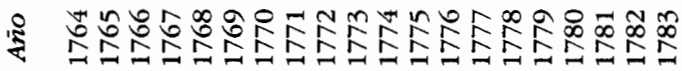


Apéndice II: Principales comerciantes igualados de la Receptoría de Cuautla de Amilpas (1777-1820)

\begin{tabular}{|c|c|c|c|c|c|}
\hline Año & Apellidos & Nombre & Razón & Lugar & Iguala \\
\hline 1777 & Escalera & Benito & Purgar y tienda & H. Tenextepango & 700 \\
\hline 1777 & García & Manuel & Purgar y tienda & H. Sta. Clara & 450 \\
\hline 1777 & Moreda & Juan & Purgar y tienda & H. Tenango & 500 \\
\hline 1777 & Ruiz Castañeda & Joaquín & Purgar y tienda & H. Calderón & 470 \\
\hline 1777 & Sarnina & Domingo & Abasto carne & Jonacatepec & 300 \\
\hline 1777 & Yurre & Andrés & Purgar y tienda & H. Mapastlán & 300 \\
\hline 1783 & Carral & José & Tienda & Cuautla & 351 \\
\hline 1783 & Castañeda & Manuel & Tienda y purgar & H.Calderón & 627 \\
\hline 1783 & Escudero & Francisco & Purgar & H. Sta. Clara & 333 \\
\hline 1783 & Flores & Micaela & Tienda y purgar & H. Tenextepango & 933 \\
\hline 1783 & Jaime & Francisco & Tienda & Cuautla & 333 \\
\hline 1783 & Moreda & Juan & Purgar & H. Tenango & 400 \\
\hline 1783 & Pellón & Manuel & Tienda & H. Casasano & 400 \\
\hline 1783 & Recio & Manuel & Purgar & H. Guadalupe & 333 \\
\hline 1783 & Recio & Manuel & Tienda & Cuautla & 400 \\
\hline 1783 & Samper & José & Tienda & Real Huautla & 400 \\
\hline 1783 & Villalobos & Agustín & Tienda y purgar & H. Sta. Inés & 333 \\
\hline 1783 & Yurre & Andrés & Tienda y purgar & H. Mapastlán & 400 \\
\hline 1789 & Canal & José & Tienda & Cuautla & 349 \\
\hline 1789 & Córdoba & Pablo & Purgar & H. Tenango & 400 \\
\hline 1789 & García & Ramón & Tienda y purgar & H. Sta. Inés & 340 \\
\hline 1789 & Hidalgo & Vicente & Tienda y purgar & H. Buenavista & 340 \\
\hline 1789 & Medrano & Carlos & Purgar & H. Casasano & 349 \\
\hline 1789 & Medrano & Carlos & Tienda & H. Casasano & 400 \\
\hline 1789 & Montero & Francisco & Purgar & H. Sta. Clara & 333 \\
\hline 1789 & Recio & Manuel & Purgar & H. Guadalupe & 334 \\
\hline 1789 & Recio & Manuel & Tienda & Cuautla & 400 \\
\hline 1789 & Ruiz Castañeda & Joaquín & Tienda y purgar & H. Calderón & 626 \\
\hline 1789 & Sarmiento & Isidoro & Tienda & Yecapixtla & 500 \\
\hline 1789 & Torrejano & José & Tienda y purgar & H. Mapastlán & 500 \\
\hline 1789 & Urbano & Mateo & Tienda y purgar & H. Tenextepango & 900 \\
\hline 1798 & Arada & Bernardo & Tienda & H. Casasano & 533 \\
\hline 1798 & Cagigal & Prudencio & Tienda & Cuautla & 400 \\
\hline 1798 & Casaval & Agustín & Tienda y purgar & H. Tenextepango & 1333 \\
\hline 1798 & Caso & Manuel & Purgar & H. Calderón & 800 \\
\hline 1798 & Cervantes & Cristóbal & Purgar & H. Tenango & 533 \\
\hline 1798 & Garcilaso & Joaquín & Estanco nicve & Cuautla & 667 \\
\hline 1798 & Lara & José & Tienda & Cuautla & 334 \\
\hline 1798 & Lara & Vicente & Purgar & H. Hospital & 400 \\
\hline 1798 & Michaus & Manuel & Purgar & H. Sta. Inés & 400 \\
\hline 1798 & Pellón & Manuel & Purgar & H. Casasano & 800 \\
\hline
\end{tabular}




$\begin{array}{llllll}\text { Año } & \text { Apellidos } & \text { Nombre } & \text { Razón } & & \text { Lugar } \\ & & & & \text { Iguala } \\ 1798 & \text { Pérez } & \text { Pedro } & \text { Tienda } & \text { H. Tenango } & 334 \\ 1798 & \text { Rico } & \text { José } & \text { Purgar } & \text { H. Sta. Clara } & 487 \\ 1798 & \text { Vélez } & \text { José } & \text { Tienda } & \text { Jonacatepec } & 334 \\ 1803 & \text { Briones } & \text { Vicente } & \text { Tienda } & \text { Jalostoc } & 600 \\ 1803 & \text { Cagigal } & \text { Prudencio } & \text { Tienda } & \text { Cuautla } & 426 \\ 1803 & \text { Chávez } & \text { José } & \text { Tienda } & \text { H. Tenextepango } & 506 \\ 1803 & \text { Chávez } & \text { José } & \text { Purgar } & \text { H. Tenextepango } & 600 \\ 1803 & \text { Garcilaso } & \text { Joaquín } & \text { Nevería } & \text { Cuautla } & 500 \\ 1803 & \text { Gómez } & \text { Juan } & \text { Purgar } & \text { H. Calderón } & 600 \\ 1803 & \text { Icazbalceta } & \text { Nicolás } & \text { Purgar } & \text { H. S. Ignacio } & 300 \\ 1803 & \text { Icazbalceta } & \text { Nicolás } & \text { Tienda } & \text { H. Sta. Clara } & 356 \\ 1803 & \text { Icazbalceta } & \text { Nicolás } & \text { Tienda } & \text { H. Tenango } & 456 \\ 1803 & \text { Icazbalceta } & \text { Nicolás } & \text { Purgar } & \text { H. Sta. Clara } & 550 \\ 1803 & \text { Icazbalceta } & \text { Nicolás } & \text { Purgar } & \text { H. Tenango } & 800 \\ 1803 & \text { Lara } & \text { Vicente } & \text { Purgar } & \text { H. Hospital } & 400 \\ 1803 & \text { Pellón } & \text { Manuel } & \text { Tienda } & \text { H. Casasano } & 488 \\ 1803 & \text { Pellón } & \text { Manuel } & \text { Purgar } & \text { H. Casasano } & 700 \\ 1815 & \text { Abariega } & \text { Bartolomé } & \text { Purgar } & \text { H. Sta. Inés } & 500 \\ 1815 & \text { Bustamante } & \text { Antonio } & \text { Tienda } & \text { H. Casasano } & 400 \\ 1815 & \text { Bustamante } & \text { Antonio } & \text { Purgar } & \text { H. Casasano } & 800 \\ 1815 & \text { Cortina } & \text { Francisco } & \text { Purgar } & \text { H. Tenextepango } & 600 \\ 1815 & \text { García } & \text { Eusebio } & \text { Purgar } & \text { H. Sta. Clara } & 800 \\ 1815 & \text { Hidalga } & \text { José } & \text { Purgar } & \text { H. Tenango } & 800 \\ 1815 & \text { Lambarri } & \text { Gabriel } & \text { Purgar } & \text { H. Calderón } & 550 \\ 1815 & \text { Michaus } & \text { Martín } & \text { Purgar } & \text { H. Buenavista } & 400 \\ 1815 & \text { Zubieta } & \text { Antonio } & \text { Purgar } & \text { H. Sta. Inés } & 800\end{array}$

Cuadro 1. Suelos alcabalatorios de la receptoría de Cuautla de Amilpas (1777-1820)

$\begin{array}{ll}\begin{array}{l}\text { Cabecera } \\ \text { Subreceptorías }\end{array} & \begin{array}{l}\text { Cuautla de Amilpas } \\ \text { Real de minas de Huautla } \\ \text { Zacualpan y pueblos altos }\end{array} \\ \begin{array}{l}\text { Agregado } \\ \text { Subreceptoría }\end{array} & \begin{array}{l}\text { Jonacatepec } \\ \text { Yecapixtla }\end{array}\end{array}$


Cuadro 2. Evolución de la recaudación de Cuautla de Amilpas respecto de la administración foránea de México (1778-1809)

$\begin{array}{cc}\text { Periodo } & \text { Porcentaje } \\ 1778-1785 & 4.89 \\ 1786-1793 & 5.01 \\ 1794-1801 & 5.40 \\ 1802-1809 & 5.79\end{array}$

Cuadro 3. Composición demográfica y recaudación de alcabalas en los suelos alcabalatorios de Cuautla y Jonacatepec

$\begin{array}{lccc}\text { Suelo alcabalatorio } & \begin{array}{c}\text { Población } \\ \text { en } 1777\end{array} & \begin{array}{c}\text { Población indigena } \\ \text { en } 1777(\%)\end{array} & \begin{array}{c}\text { Recaudación de alcabalas } \\ (1778-1820)(\%)\end{array} \\ \text { Cuautla Amilpas } & 12932 & 60 & 68.1 \\ \text { Jonacatepec } & 14700 & 71 & 31.9 \\ \text { Total } & 27632 & 66 & 100\end{array}$

FUEN'T: AGI, Indiferente, leg. 102, 1525 y 1527.

Cuadro 4. Composición de las alcabalas de la Receptoría de Cuautla de Amilpas (1778-1820)

$\begin{array}{lc}\text { Rubro } & \text { Porcentaje } \\ \text { Igualas } & 68 \\ \text { Viento } & 15 \\ \text { Tierra } & 7 \\ \text { Castilla } & 1 \\ \text { Inmuebles } & 9\end{array}$


Cuadro 5. Productos comercializados por indígenas en Cuautla de Amilpas (1792)

$\begin{array}{lclc}\text { Producto } & \text { Porcentaje } & \text { Producto } & \text { Porcentaje } \\ \text { Algodón } & 18 & \text { Petates } & 4 \\ \text { Zapatos } & 14 & \text { Frijol } & 4 \\ \text { Ropa de la tierra } & 11 & \text { Clacoyaques } & 3 \\ \text { Sillas } & 10 & \text { Reses } & 3 \\ \text { Chile } & 7 & \text { Paños } & 2 \\ \text { Sal } & 7 & \text { Varios } & 8 \\ \text { Mercería } & 4 & \text { Total } & 100\end{array}$

Cuadro 6. Composición interna de las igualas de Cuautla de Amilpas

$\begin{array}{ccccccccc}\text { Año } & \begin{array}{c}\text { Purgar } \\ \text { bacienda }\end{array} & \begin{array}{c}\text { Tienda } \\ \text { ypurgar }\end{array} & \begin{array}{c}\text { Tienda } \\ \text { bacienda }\end{array} & \text { Rancho } & \text { Tienda } & \begin{array}{c}\text { Tendajo } \\ \text { changarro }\end{array} & \text { Otros } & \text { Total } \\ 1777 & - & 3170 & 830 & 272 & 4694 & 276 & 170 & 9420 \\ 1783 & 1093 & 2626 & 1607 & 84 & 3940 & 9 & 148 & 11800 \\ 1789 & 1790 & 2604 & 1081 & - & 4553 & 345 & - & 10010 \\ 1798 & 3886 & 1707 & 1789 & 34 & 4653 & - & 667 & 12734 \\ 1803 & 4560 & - & 3091 & 288 & 5738 & 524 & - & 14709 \\ 1815 & 5250 & - & 1385 & - & 805 & 537 & 168 & 8145\end{array}$

Cuadro 7. Distribución de los comerciantes de Cuautla de Amilpas según sus igualas $(1777-1820)$

Porcentaje

Comerciantes con igualas inferiores a 101 pesos Comerciantes con igualas entre 101 y 200 pesos Comerciantes con igualas entre 201 y 300 pesos Comerciantes con igualas superiores a 301 pesos Total
Porcentaje de iguala pagada

$\begin{array}{rr}56 & 13 \\ 16 & 16 \\ 13 & 20 \\ 15 & 51 \\ 100 & 100\end{array}$


Gráfica 1. Recaudación mensual de las alcabalas de Cuautla de Amilpas (1778-1793)

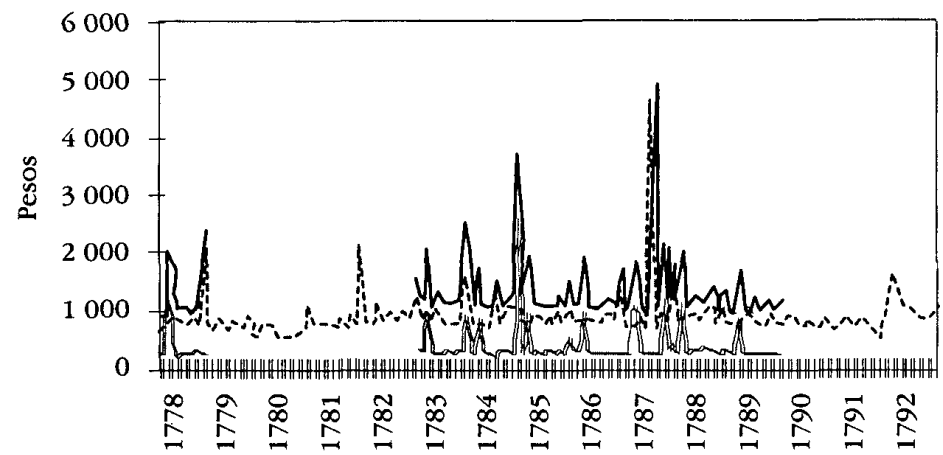

Cuautla

Jonacatepec Total

FuENTE: AGN, Aduanas foráneas, Real Hacienda-Indiferente.

Gráfica 2. Recaudación indulto del aguardiente de caña y su alcabala en Cuautla de Amilpas (1797-1818)

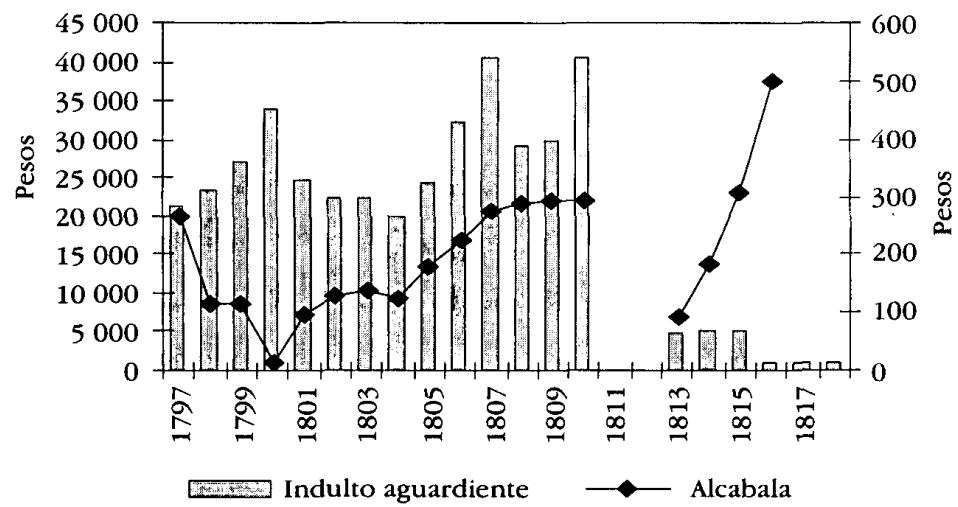

FUENTE: AGN, Alcabalas, vol. 317. 
Gráfica 3. Evolución de las igualas en Cuautla de Amilpas (1778-1820)

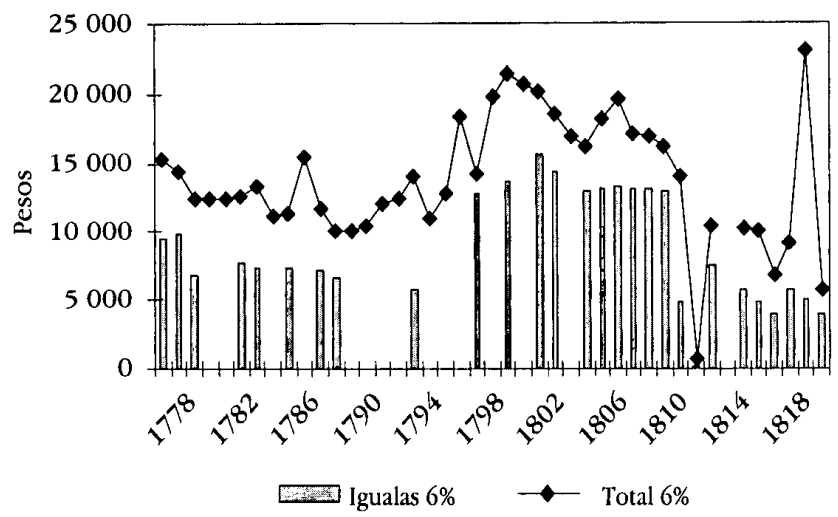

FUENTE: Aduanas foráneas, Real Hacienda-Indiferente y Alcabalas, vol. 317.

Gráfica 4. Recaudación bruta de alcabalas en Cuautla de Amilpas (1764-1820)

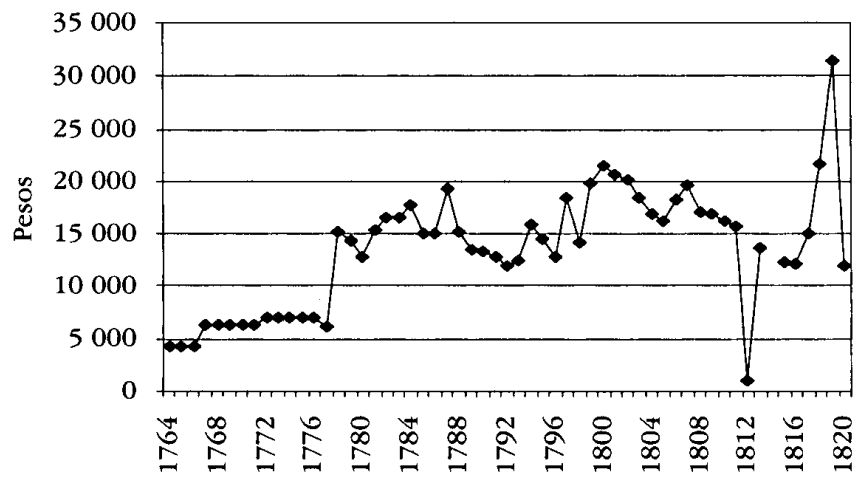

FUENTE: Apéndice I. 
Gráfica 5. Recaudación bruta al $6 \%$ de las alcabalas de Cuautla de Amilpas

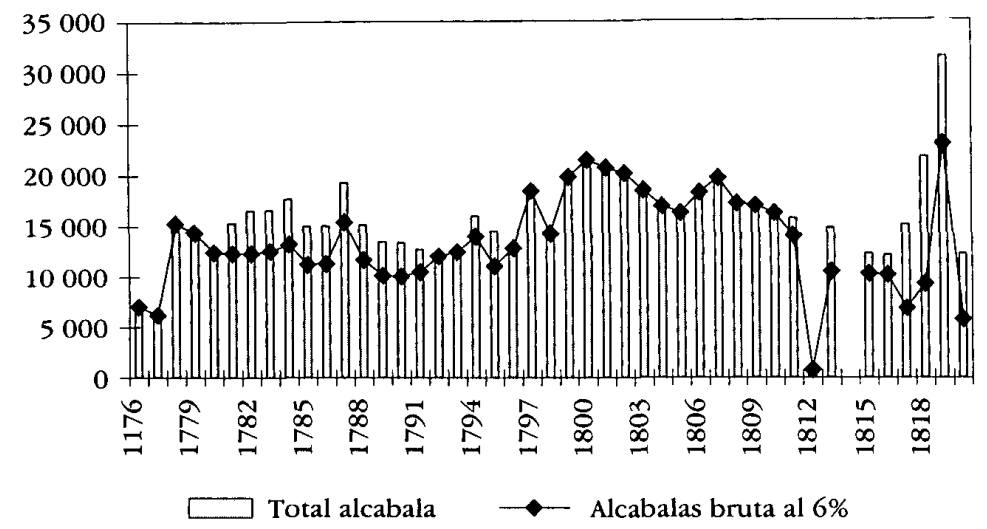

FuENTE: Apéndice 1.

Gráfica 6. Tendencia de la renta de alcabalas en Cuautla de Amilpas (1778-1810)

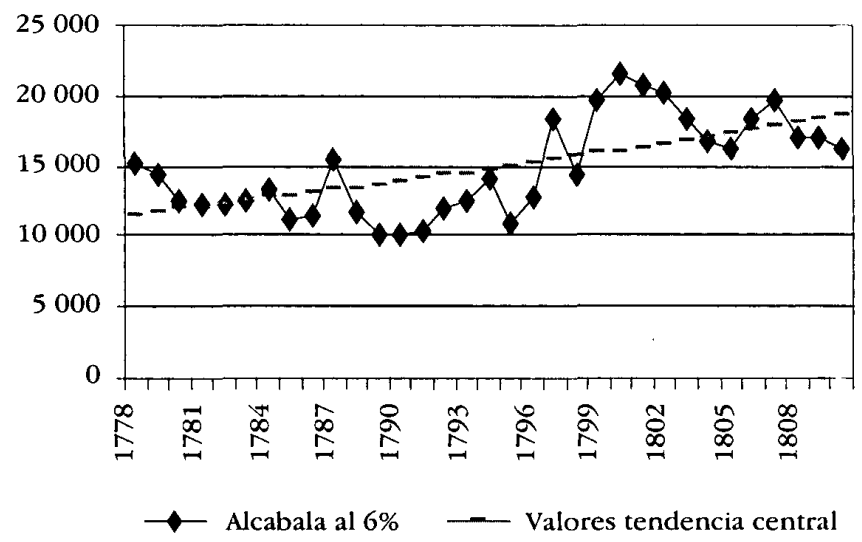

FUENTE: Apéndice I. 


\section{SECUENCIA}

Gráfica 7. Recaudación de alcabalas y de indulto de aguardiente de caña en Cuautla de Amilpas (1797-1818)

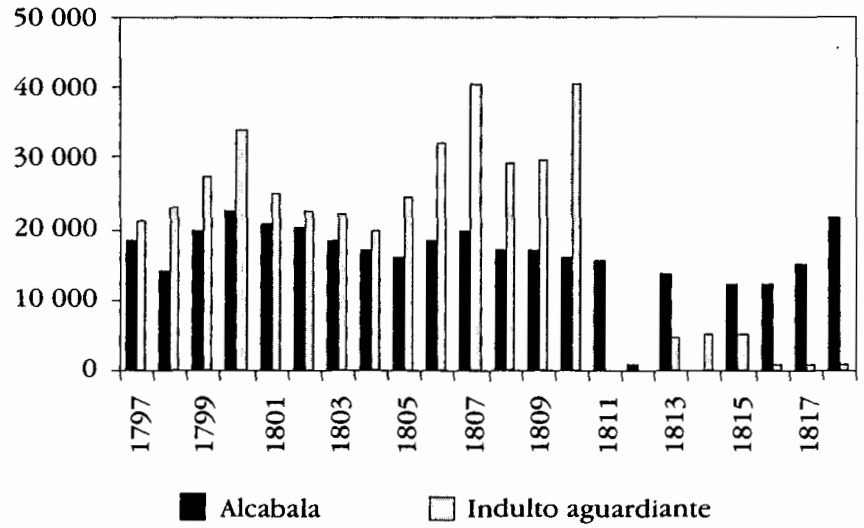

FUENTE: Apéndice I y AGN, Alcabalas, vol. 317.

Gráfica 8. Recaudación de alcabalas en Cuautla de Amilpas (1810-1820)

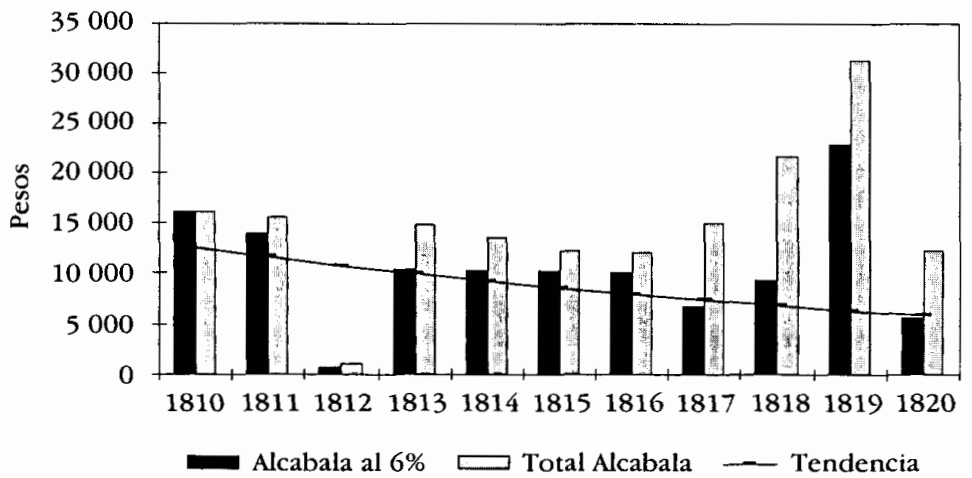

FUENTE: Apéndice I (1814 interpolado). 
Mapa 1. Receptoría de alcabalas de Cuautla de Amilpas

1776-1821

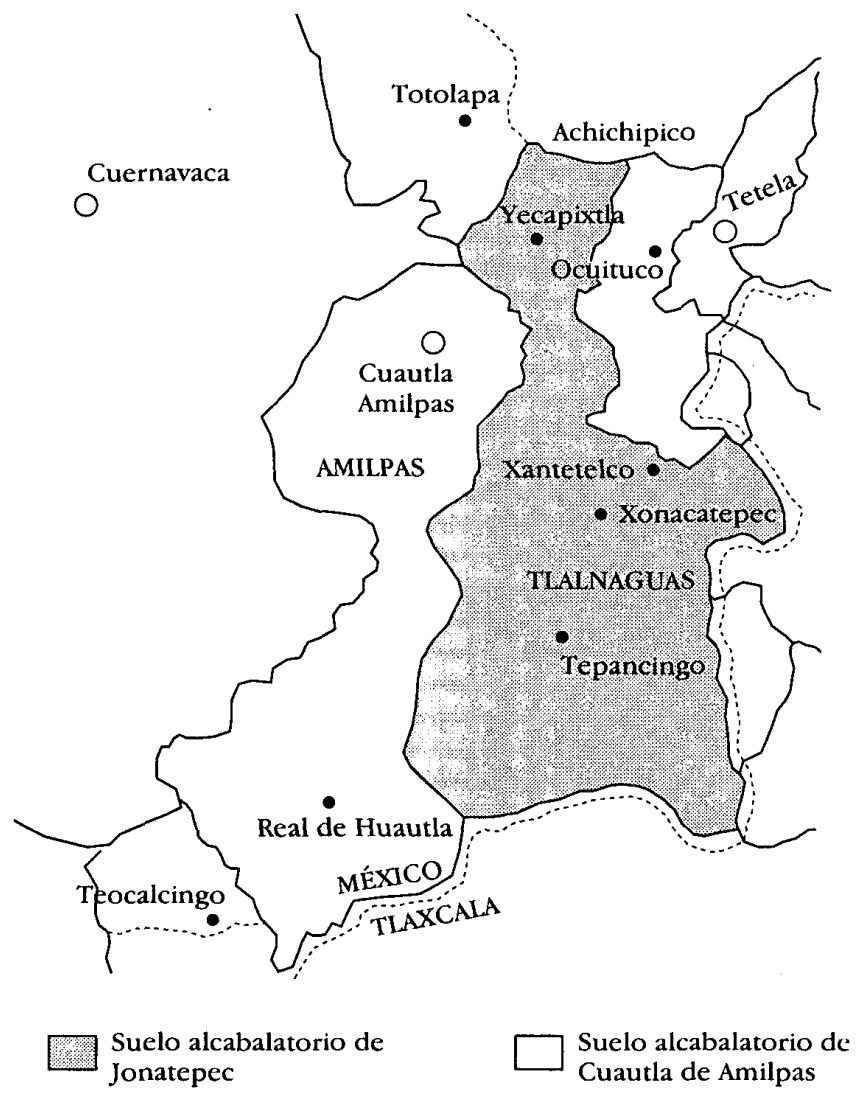

FuENTE: Gerhard, Geografía, 1986, p. 94. Reelaborado: José Luis Barajas Erelva, Centro Multimedia-UAEM. 